\title{
Determinants of Health Behaviors and Obesity in Turkey ${ }^{1}$
}

\author{
Aysit TANSEL (https://orcid.org/0000-0001-9556-2396), Department of Economics, Middle East Technical \\ University, Turkey; Institute of Labor Economics (IZA) Bonn, Germany; Economic Research Forum (ERF) \\ Cairo,Egypt; e-mail: atansel@metu.edu.tr
}

Deniz KARAOĞLAN (https://orcid.org/0000-0002-8000-8613), Department of Economics, Bahçeşehir University, Turkey; e-mail: hanifedeniz.karaoglan@eas.bau.edu.tr

\section{Türkiye’de Sağlık Davranışlarını ve Obeziteyi Belirleyici Faktörler²}

\begin{abstract}
The purpose of this paper is to examine the determinants of health behaviors and obesity with an emphasis on education in Turkey. We use Health Survey of Turkish Statistical Institute for the years 2008, 2010 and 2012. The health behaviors considered are smoking, alcohol consumption, fruit and vegetable consumption, and exercise. We consider both the years of schooling and the different levels of education in order to better understand the association between education and health. We find that education is the most important factor associated with the health behaviors and obesity. Smoking is positively associated with education at all levels with a decreasing effect with the level of education unlike in the developed countries. Alcohol consumption is positively related with education and this association increases with the level of education. Higher educated individuals clearly eat more fruits, vegetables and exercise more and they are less likely to be obese compared to the less educated and the illiterate. We also highlight the importance of demographic factors, labor market status and household income in determining health behaviors and obesity.
\end{abstract}

Keywords : Health Behaviors, Education, Demographic Factors, Turkey.

JEL Classification Codes : I10, I12, I19.

\section{Öz}

$\mathrm{Bu}$ çalışmanın amacı, Türkiye'deki sağlık davranışları ve obezite belirleyicilerini eğitim üzerine vurgu yaparak incelemektir. Çalışmanın analizleri 2008, 2010 ve 2012 yılları için Türkiye İstatistik Kurumu tarafından hazırlanan Sağlık Araştırması veri seti kullanılarak yapılmıştır. Çalışmada ele alınan sağlık davranışları sigara tüketimi, alkol tüketimi, meyve ve sebze tüketimi ve düzenli

1 This paper is based on Deniz Karaoğlan's dissertation (see Karaoğlan, 2015) prepared under the supervision of Aysit Tansel at the Department of Economics, METU. Ms. Karaoğlan would like to thank Meltem DayloğluTayfur, Illhan Can Özen, Çagla Ökten and Nur Asena Caner for helpful comments on her dissertation. Thanks are also due to Mehmet Günal, responsible for health statistics group at the Turkish Statistical Institute for his kind help in implementing this study. Any errors are our own.

2 Bu makale Deniz Karaoğlan 'in ODTU İktisat bölümünde Aysıt Tansel danışmanlığında hazırladığı doktora tez çalışmasından yapılmıştır (bakınız, Karaoğlan (2015)). Doktora tezinin ilerlemesinde yaptıkları yorumlarla katkıda bulunan Meltem Dayıoğlu-Tayfur, İlhan Can Özen, Çağla Ökten ve Nur Asena Caner'e teşekkür ediyoruz. Ayrıca, Türkiye İstatistik Kurumun'da sağllk istatistiklerinden sorumlu Mehmet Günal'a çalışmanın uygulanabilmesi için yaptığı yardımlardan dolayı teşekkür ediyoruz. Çalışmada yanlışlıklar varsa, kendi hatalarımızdan kaynaklanmaktadır. 
egzersizdir. Çalışmada kişinin eğitim seviyesi ve sağlık davranışları arasındaki ilişkiyi daha iyi anlamak için farklı analizlerde eğitim değişkeni olarak kişinin tamamlanmış okul yılı ve eğitim düzeylerini belirten kukla değişkenler kullanılmıştır. Çalışmanın sonunda eğitim seviyesinin kişinin hem sağlık davranışlarını hem de obez olma olasılığını açıklayan en önemli faktör olduğu saptanmıştır. Tamamlanan eğitimin her kademesinde sigara tüketimi ve okula gidilen yıl sayısı arasında pozitif bir ilişki bulunmuştur. Türkiye'de eğitim ve sigara tüketimi arasındaki bu pozitif ilişki, gelişmiş ülkeler için yapılan benzer çalışmalar ile çelişmektedir. Alkol tüketimi eğitim seviyesi ile pozitif ilişkilidir ve eğitim düzeyinin artması ile beraber bu ilişki kuvvetlenmektedir. Çalışmanın sonucunda eğitim seviyesi daha yüksek kişilerin daha fazla meyve, sebze tükettikleri ve egzersiz yaptıkları saptanmıştır. Eğitim seviyesi yüksek kişilerin obez olma olasılığının daha düşük olduğu sonucuna varılmıştır. Son olarak, çalışmada sağlık davranışlarının ve obez olma olasılığının belirlenmesinde demografik faktörlerin, kişinin işgücü piyasası durumunun ve hanehalkı gelirinin önemi vurgulanmıştır.

Anahtar Sözcükler : Sağlık Davranışları, Eğitim, Demografik Faktörler, Türkiye.

\section{Intoduction}

Determinants of the variations in health behaviors and outcomes have attracted several authors in health economics literature. In the literature, education is found to be one of the major determinants of individual's health behaviors and health outcomes. Grossman (1972) is one of the earliest studies which provide formal explanations of the observed differences in health behaviors by education. Later on, Cutler and Lleras-Muney (2008) and a number of studies focus on differences in life-expectancy by education in the US and the UK. Lleras-Muney (2005) examines the relationship between adult mortality and education and in the US. Cutler and Lleras-Muney (2010) emphasize that health outcome differences by education need to be explained by health behavior differences by education. These differentials in health behaviors by education are studied mostly in developed countries. However, there is less evidence on this issue in developing countries. We believe that the results may differ in developing countries because their income and education levels are lower and their health services may be scarcer compared to the developed countries. Therefore, in this paper we examine the determinants of health behaviors, as well as obesity, with an emphasis on education in Turkey which is a developing country. In addition, we highlight the differences in health behaviors and probability of being obese by other indicators such as demographic factors, labor market status and household income. We should clearly mention that in this paper, we attempt to establish the correlations between health behaviors and their determining factors rather than investigate causality.

Health behaviors considered in this study are smoking, alcohol consumption, fruit and vegetable consumption, exercise and the health outcome considered in this study is obesity. We refer smoking as risky health behavior that negatively affects individual's health, whereas we assume that regular fruit and vegetable consumption and exercise lead to improvement in individual's health. Alcohol consumption is not referred as risky health behavior in this study, since we refer both occasional drinkers and heavy drinkers as alcohol 
consumers $^{3}$. Among the health behaviors and health outcome we consider, smoking and obesity are the ones that are examined most often in the literature. Example of these studies include Mullahy (1997), Chaloupka and Warner (2000), Cutler et al. (2003), Carbone et al. (2005), Cutler and Gleaser (2005), Gruber and Frakes (2006), and de Walque (2007). There are several studies which investigate the relationship between health behaviors and various educational and demographic factors that might influence them. Cutler and Lleras-Muney (2010) study this relationship in the USA and the UK. An earlier study, Kenkel (1991) and Lantz et al (1998 and 2001) also investigate this relationship in the USA. Ettner (1996) examines the effect of socioeconomic status of the individual and alcohol consumption in the USA. There are also studies that examine the relationship between health behaviors and education for developed countries other than the UK and the USA. For instance, Kemptner et al. (2011) examine this relationship for West-Germany. They look at the association between education and smoking as well as obesity. Brunello et al. (2013) examine the relationship between education and obesity for the case of 13 European countries. Webbink et al. (2010) examine the education and obesity relationship in Australia (2010). It is important to note that these studies do not always find the expected negative association between risky health behaviors and education. For instance, Kemptner et al. (2011) find that although an increase education level decreases the likelihood of being obese for both men and women in West-Germany, there is no significant link between education and smoking.

Previous literature on the determinants of health behaviors in Turkey is very limited and mostly focus on one health behavior at a time. For instance, Tansel (1993) examines the cigarette smoking in Turkey. She finds a larger decrease in demand for cigarettes if people are educated about the harmful effects of smoking than if there is an increase in cigarette prices. In another study, Erem et al. (2004) investigate the determinants of obesity in Trabzon, a city located in the Black Sea region of Turkey. They find that obesity increases with age and it is more prevalent among women than among men. Hatemi et al. (2003) study the relationship between hypertension and obesity for 11 cities in Turkey. Other studies related to the determinants of health behaviors in Turkey include Metintaş et al. (1998), Erbaydar et al. (2005), Kocabaş et al. (1994) and Yumuk (2005). This paper is the first paper that examines the association between several health behaviors, as well as obesity and individual's socio-economic factors with an emphasis on education by using a rich micro data set. We should stress that in this paper we are interested in associations in order to make policy suggestions. For instance, the causal effect of education on health behaviors is not the scope of this paper ${ }^{4}$.

3 Since the proportion of the individuals who report that they are heavy drinkers is very low in the data set we use, in order to examine the variations in alcohol consumption, we should include both heavy drinkers and occasional drinkers as alcohol consumers. Therefore, following Kenkel (1991) we cannot refer alcohol consumption as risky health behavior. The details will be mentioned in Data and Variables section.

4 Tansel and Karaoğlan (2019) reports on the causal effect of education on several health behaviors in Turkey by using the same data set. They implement their analysis for the same age group as this study. The causal nature 
In this study, we examine the determinants of health behaviors and obesity focusing on education for the adult population in Turkey using Turkish Health Survey data set for the years 2008, 2010 and 2012. Probit models are estimated for several health behaviors and obesity. We consider both the years of schooling and the different levels of education in order to better understand the relationship between education and health. The correlation between education and health behaviors is a well-established result in the literature. We also consider demographic factors, labor market status and household income. We find that among all the factors considered education has the strongest association with the health behaviors. University graduates tend to smoke less, consume more fruits and vegetables, and exercise more frequently than less educated individuals. In addition, they have less tendency to be obese compared to the less educated ones. We also find that highly educated people tend to consume more alcohol than less educated people.

The rest of the paper is organized as follows. Section 2 presents the theoretical framework. Section 3 provides a description of the Turkish Health Survey data used in this study, provides information about the variables and presents the descriptive statistics. Section 4 describes the empirical specification used in estimation. Section 5 presents the empirical results. Finally, concluding remarks are provided in Section 6.

\section{Theoretical Framework}

The first theoretical model of demand for health is developed by Grossman (1972). Grossman emphasizes that health is a durable capital stock that deteriorates with time. He argues that health capital is different from education in the sense that while education determines the individual's time productivity (such as wages), the stock of health determines the total amount of productive time an individual uses freely. The relationship between these two forms of human capital is examined in Grossman's model where education is determined exogenously. He concludes that education is positively associated with health capital and negatively associated with expenditures on health care. Other conclusions include the following: Demand for health also varies with the given rate of depreciation of the stock of health. The depreciation rate rises with age and falls with higher levels of education. As a result, demand for good health decreases and expenditure on medical care increases with age. The associations of wage rate with the demand for good health and health care are positive. Higher levels of education enhance the wage rate and wage rate improves the quality of individual's health capital.

Bolin (2011) extends Grossman's (1972) model to continuous time. He solves the individual's utility maximization problem and derives predictions on how education, age and wage rate affect the individual's health level. He argues that education influences the demand for health in two ways. First, education enhances household production efficiency 
(the efficiency effect), second, education increases the cost of own time used in household production since it rises the market productivity and hence the wage rate (the time-price effect). The production efficiency effect decreases the marginal cost of producing health capital since fewer resources are used to produce a certain quantity of gross health investments. Therefore, production efficiency effect increases the demand for health. On the other hand, the time price effect causes a decrease in health demand because marginal cost of health capital increases due to a higher unit cost of own time. However, the two effects cannot completely offset each other, since individual's own time is not the only input to health production and production effect outweighs the time-price effect. In other words, the positive effect of education always dominates its negative effect. In Bolin's model a higher wage rate increases the value of available healthy time, therefore as wage increases, the incentives for being healthy strengthen. On the other hand, higher wage rate makes own time used for producing gross investments in health more expensive. A higher cost of own time will increase the marginal cost of health capital leading to a decrease in the demand for health. As in the education case, the positive effect of wage rate on health always dominates the negative effect of wage rate on health since individual's own time is not the only input that produces health. In Bolin's model as age increases, the possibility of having a certain level of good health decreases. As the rate of depreciation increases over time, the model predicts that the demand for good health decreases with age. Because of the higher depreciation rate at older ages the equilibrium amount of health therefore the demand for good health for the old individual is lower than that for the young individual.

Theoretically, health behaviors are considered as inputs for health production. In Grossman's both 1972 and 2000 health demand models medical care is the only health input. However, as Grossman (2000) suggests, it is an oversimplification because other market goods and services such as housing, diet, recreation, cigarette smoking, and excessive alcohol consumption also influence health. According to Grossman smoking and excessive alcohol consumption have negative marginal products in the production of health. However, they are purchased since they may have positive marginal products in producing pleasure commodities such as "smoking pleasure".

In this paper, our empirical specification is mostly based on Grossman (1972). We assume that education exogenously affect the individual's health as Grossman (1972) suggests. In addition, like Grossman (2000) we make an oversimplification such that we consider the health behaviors such as smoking and alcohol consumption as health outcome rather than health input. The details of our empirical specification are discussed in section 4.

\section{The Data and Variables}

This study uses the results of Turkish Health Survey (THS) for the years 2008, 2010 and 2012. THS is cross sectional data set over individuals. It is conducted by Turkish Statistical Institute (TURKSTAT) in 2008, 2010, and 2012. The surveys are conducted during late spring or early summer on nationally representative samples. Two-stage stratified cluster sampling methods are implemented to establish the samples. In the survey health 
related questions are asked separately for 3 different age groups, 0-6, 7-14 and 15 or above. In this paper, we focus on the individuals 25 years of age or over since individuals are assumed to complete their schooling around the age of 25 . We do not observe significant differences in the main results when we use the three survey years separately. Therefore, we pool the THS of 2008, 2010 and 2012 in our analysis of the determinants of health behaviors in Turkey ${ }^{5}$. Details of variable definitions are given in Tables A1 and A2 in the appendix section.

In the THS, we observe the demographic characteristics of the respondents 15 or over, such as age, gender, education level, marital status as well as household income, region (urban/rural) and labor market status (employed, unemployed or out of labor force). Marital status is indicated as married, single or widowed/divorced. The respondent is referred as widowed if his/her spouse is dead and he/she is referred as divorced if he/she is separated legally. Since widowed and divorced individuals have similar history we include them into one group. We define the years of schooling in the following manner: If the individual is illiterate, the years of schooling assigned 0 . If the individual is literate but not a graduate of any school, then the years of schooling is equal to 2 . The individual's years of schooling is equal to 5,8 or 11 if he/she has completed primary, middle and high school respectively. Finally, the individual's years of schooling is equal to 15 if the individual has university or higher degree. In addition, we use the six education groups in our regression analysis. These categories are illiterate, literate without a diploma (non-graduate), and graduates of primary school, middle school, high school and university or higher degree. Finally, we consider three labor market statuses such as employed, unemployed and inactive. The respondents who have a regular job are referred to as "employed", whereas the individuals who are not working but are seeking job are considered as "unemployed". The respondents who are seasonal workers, students, housewives, pensioners, and the individuals who are unable to work are considered as inactive or out of labor market.

In this study, the health behaviors considered are smoking, alcohol consumption, fruit and vegetable consumption, exercise and the health outcome is obesity. If the respondent were a regular smoker or currently smokes every day or sometimes then the individual is considered as a "smoker". In the empirical model for smoking behavior the dependent variable is equal to 1 if the individual is a "smoker" and 0 otherwise. Similarly, if the respondent were a regular drinker or currently drinks every day or sometimes then the individual is considered as an "alcohol consumer". In our empirical model for alcohol consumption behavior the dependent variable is equal to 1 if the individual is an "alcohol consumer" and 0 otherwise. The individual is considered to be regular fruit and vegetable consumer if he/she consumes fruits, vegetables and/or their juice at least once a week. Then the health behavior outcome is equal to 1 if the individual is a regular fruits and vegetable 
consumer and 0 otherwise. In THS, physical exercise is divided into three categories: High level exercise (such as aerobic exercise or working in the construction sector), medium level exercise (such as riding a bicycle or house work) and low-level exercise (such as walking). The number of days in a reference week in which the respondent exercises using one of the above ways for at least 10 minutes gives the frequency of exercise in a week. Then the health behavior outcome is equal to 1 if the individual exercises at a high level or medium level or low level for at least 10 minutes in the reference week and 0 if he/she does not exercise in the reference week. Finally, we use the self-reported height (in meters) and weight (in kilograms) in order to calculate the BMI of an individual. According to the World Health Organization (WHO) criteria, an individual is considered as underweight if his/her BMI is under 18.5. He/she is normal weight if the BMI is within the range of 18.5-24.99. The individual is considered as overweight if his/her BMI is in the range of 25-30, and a BMI level greater than 30 indicates that the individual is obese. Therefore, the health outcome variable equals to 1 if the individual's BMI level is greater than 30, and equals to 0 otherwise.

\subsection{Smoking}

OECD (2016) reports that 23.8 per cent of adult population in Turkey is regular smoker which is the third highest after Latvia (34.8 per cent) and Estonia (26 per cent) among the OECD countries in 2012. Smoking is one of the most harmful health behaviors. Regular smokers are in great risk for cardiovascular disease, chronic lung disease and several types of cancer (Stewart et al., 2009; Chalupka \& Warner, 2000). In the THS data set smoking implies consumption of all types of tobacco products. We define an individual as smoker if he/she has been a regular smoker or he/she currently smokes. Table 1 presents the descriptive statistics for smoking using the pooled 2010 and 2012 surveys $^{6}$.

We observe that years of schooling is higher among smokers than nonsmokers. Nevertheless, the prevalence of smoking is highest among middle school graduates. We also note that among males the percentage of smokers is larger than nonsmokers. The fraction of smokers is higher in urban areas than in rural areas. Comparing people of different marital statuses, we see that the proportion of the smokers is highest among the singles. Regarding the employment status, we see that percentage of smokers among unemployed is higher than those among the employed and inactive individuals. Finally, we see that household income is slightly higher among smokers. 
Table: 1

Descriptive Statistics for Smoking ${ }^{7}$

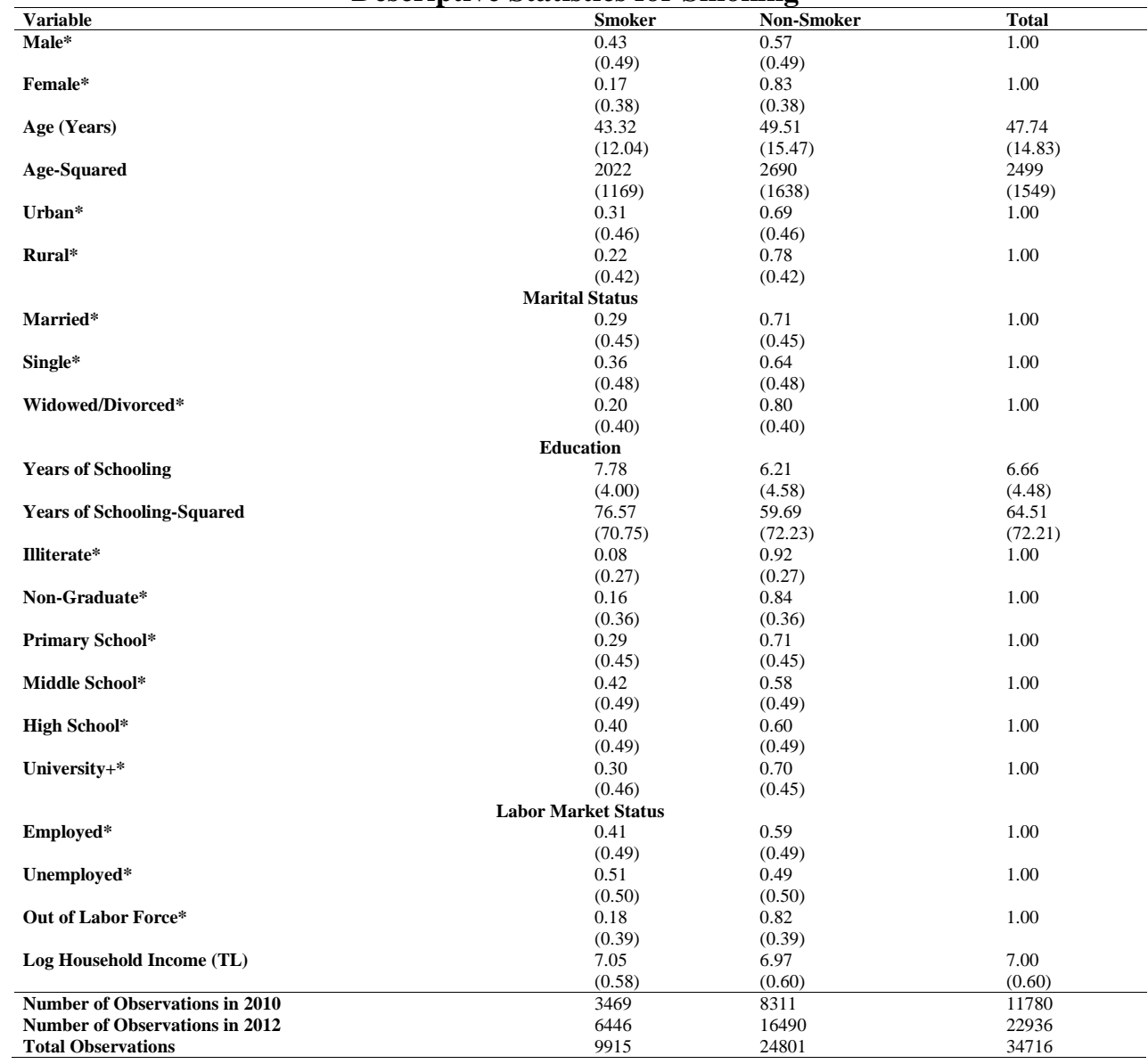

7 For all the Tables in Section 3:

Source: Authors' computations using 2008, 2010 and 2012 Turkish Health Survey (Except for Smoking: For Smoking, data source is 2010 and 2012 Turkish Health Survey data set, since smoking data for 2008 is not available.

For all the descriptive Statistics Tables

Notes:

(1) * indicates a dummy variable.

(2) The numbers in the paranthesis are standard deviations. 
Table: 2

Descriptive Statistics for Alcohol Consumption

\begin{tabular}{|c|c|c|c|}
\hline Variable & Alcohol Consumer & Non-Alcohol Consumer & Total \\
\hline Male* & $\begin{array}{l}0.20 \\
(0.40)\end{array}$ & $\begin{array}{l}0.80 \\
(0.40)\end{array}$ & 1.00 \\
\hline Female* & $\begin{array}{l}0.04 \\
(0.21)\end{array}$ & $\begin{array}{l}0.96 \\
(0.21)\end{array}$ & 1.00 \\
\hline Age (Years) & $\begin{array}{l}43.52 \\
(12.00)\end{array}$ & $\begin{array}{l}47.91 \\
(15.06)\end{array}$ & $\begin{array}{l}47.41 \\
(14.81)\end{array}$ \\
\hline Age-Squared & $\begin{array}{l}2038 \\
(1150)\end{array}$ & $\begin{array}{l}2522 \\
(1577)\end{array}$ & $\begin{array}{l}2466 \\
(1541)\end{array}$ \\
\hline Urban* & $\begin{array}{l}0.13 \\
(0.34)\end{array}$ & $\begin{array}{l}0.87 \\
(0.34)\end{array}$ & 1.00 \\
\hline Rural* & $\begin{array}{l}0.08 \\
(0.27)\end{array}$ & $\begin{array}{l}0.92 \\
(0.27)\end{array}$ & 1.00 \\
\hline Married* & $\begin{array}{ll} & \text { Marital Sta } \\
0.11 & \\
(0.32) & \end{array}$ & $\begin{array}{l}0.89 \\
(0.32)\end{array}$ & 1.00 \\
\hline Single* & $\begin{array}{l}0.20 \\
(0.40)\end{array}$ & $\begin{array}{l}0.80 \\
(0.40)\end{array}$ & 1.00 \\
\hline Widowed/Divorced* & $\begin{array}{l}0.06 \\
(0.25)\end{array}$ & $\begin{array}{l}0.94 \\
(0.25)\end{array}$ & 1.00 \\
\hline Years of Schooling & $\begin{array}{l}9.63 \\
(4.16)\end{array}$ & $\begin{array}{l}6.14 \\
(4.33)\end{array}$ & $\begin{array}{l}6.54 \\
(4.45)\end{array}$ \\
\hline Years of Schooling-Squared & $\begin{array}{l}110.11 \\
(81.60)\end{array}$ & $\begin{array}{l}56.35 \\
(67.17)\end{array}$ & $\begin{array}{l}62.52 \\
(71.08)\end{array}$ \\
\hline Illiterate* & $\begin{array}{l}0.01 \\
(0.07)\end{array}$ & $\begin{array}{l}0.99 \\
(0.07)\end{array}$ & 1.00 \\
\hline Non-Graduate* & $\begin{array}{l}0.02 \\
(0.15)\end{array}$ & $\begin{array}{l}0.98 \\
(0.15)\end{array}$ & 1.00 \\
\hline Primary School* & $\begin{array}{l}0.08 \\
(0.28)\end{array}$ & $\begin{array}{l}0.92 \\
(0.28)\end{array}$ & 1.00 \\
\hline Middle School* & $\begin{array}{l}0.16 \\
(0.37)\end{array}$ & $\begin{array}{l}0.84 \\
(0.37)\end{array}$ & 1.00 \\
\hline High School* & $\begin{array}{l}0.18 \\
(0.39)\end{array}$ & $\begin{array}{l}0.82 \\
(0.39)\end{array}$ & 1.00 \\
\hline University+* & $\begin{array}{l}0.27 \\
(0.45)\end{array}$ & $\begin{array}{l}0.73 \\
(0.45)\end{array}$ & 1.00 \\
\hline Employed* & $\begin{array}{l}\text { Labor Market } \\
0.20 \\
(0.40)\end{array}$ & $\begin{array}{l}0.80 \\
(0.40)\end{array}$ & 1.00 \\
\hline Unemployed* & $\begin{array}{l}0.20 \\
(0.40)\end{array}$ & $\begin{array}{l}0.80 \\
(0.40)\end{array}$ & 1.00 \\
\hline Out of Labor Force* & $\begin{array}{l}0.05 \\
(0.22)\end{array}$ & $\begin{array}{l}0.95 \\
(0.22)\end{array}$ & 1.00 \\
\hline Log Household Income (TL) & $\begin{array}{l}7.19 \\
(0.60)\end{array}$ & $\begin{array}{l}6.88 \\
(0.61) \\
\end{array}$ & $\begin{array}{l}6.92 \\
(0.62)\end{array}$ \\
\hline Number of Observations in 2008 & $\begin{array}{l}1338 \\
1495\end{array}$ & 10439 & 11777 \\
\hline $\begin{array}{l}\text { Number of Observations in } 2010 \\
\text { Number of Observations in } 2012\end{array}$ & $\begin{array}{l}1495 \\
2500\end{array}$ & $\begin{array}{l}10285 \\
20436\end{array}$ & $\begin{array}{l}11780 \\
22936\end{array}$ \\
\hline Total Observations & 5333 & 41160 & 46493 \\
\hline
\end{tabular}

\subsection{Alcohol Consumption}

According the OECD (2016) alcohol consumption is only 1.5 liters per capita in Turkey in 2014. This amount is very low compared to other OECD countries. The low level of alcohol consumption in Turkey is most probably due to the religious traditions which prohibit alcohol consumption. Similarly, in THS the proportion of daily alcohol drinkers is very low, less than one percent $(0.5,0.4$, and 0.2 per cents in 2008, 2010 and 2012 respectively). In order to capture some variation in alcohol consumption, we combine the daily and occasional alcohol drinkers. We refer to an individual as alcohol consumer if he/she currently consumes alcohol regularly or occasionally. Grossman (2000) states that smoking and excessive alcohol consumption have negative marginal products in the production of health. Neverheless, since some alcohol consumption is even good for 
individual's health (Kenkel, 1991) we consider alcohol consumption as health behavior, rather than risky health behavior throughout the analysis. Table 2 reports the descriptive statistics for alcohol consumption.

Table: 3

Descriptive Statistics for Fruit and Vegetables (FV) Consumption

\begin{tabular}{|c|c|c|c|}
\hline \multirow{2}{*}{$\begin{array}{l}\text { Variable } \\
\text { Male* }\end{array}$} & Consume FV Regularly & Not Consume FV & \multirow{2}{*}{$\begin{array}{l}\text { Total } \\
1.00\end{array}$} \\
\hline & $\begin{array}{l}0.59 \\
(0.49)\end{array}$ & $\begin{array}{l}0.41 \\
(0.49)\end{array}$ & \\
\hline Female* & $\begin{array}{l}0.57 \\
(0.49)\end{array}$ & $\begin{array}{l}0.43 \\
(0.49)\end{array}$ & 1.00 \\
\hline Age (Years) & $\begin{array}{l}46.72 \\
(14.68)\end{array}$ & $\begin{array}{l}48.34 \\
(14.93)\end{array}$ & $\begin{array}{l}47.40 \\
(14.81)\end{array}$ \\
\hline Age-Squared & $\begin{array}{l}2398 \\
(1516)\end{array}$ & $\begin{array}{l}2559 \\
(1571)\end{array}$ & $\begin{array}{l}2466 \\
(1541)\end{array}$ \\
\hline Urban* & $\begin{array}{l}0.60 \\
(0.49)\end{array}$ & $\begin{array}{l}0.40 \\
(0.49)\end{array}$ & 1.00 \\
\hline Rural* & $\begin{array}{l}0.54 \\
(0.50)\end{array}$ & $\begin{array}{l}0.46 \\
(0.50)\end{array}$ & 1.00 \\
\hline Married* & $\begin{array}{ll} & \text { Marital Status } \\
0.58 & \end{array}$ & $\begin{array}{l}0.42 \\
(0.49)\end{array}$ & 1.00 \\
\hline Single* & $\begin{array}{l}0.65 \\
(0.48)\end{array}$ & $\begin{array}{l}0.35 \\
(0.48)\end{array}$ & 1.00 \\
\hline Widowed/Divorced* & $\begin{array}{l}0.54 \\
(0.50)\end{array}$ & $\begin{array}{l}0.46 \\
(0.50)\end{array}$ & 1.00 \\
\hline \multicolumn{4}{|c|}{ Education } \\
\hline Years of Schooling & $\begin{array}{l}6.85 \\
(4.46)\end{array}$ & $\begin{array}{l}6.11 \\
(4.39)\end{array}$ & $\begin{array}{l}6.54 \\
(4.45)\end{array}$ \\
\hline Years of Schooling-Squared & $\begin{array}{l}66.80 \\
(72.81)\end{array}$ & $\begin{array}{l}56.68 \\
(68.19)\end{array}$ & $\begin{array}{l}62.55 \\
(71.08)\end{array}$ \\
\hline Illiterate* & $\begin{array}{l}0.50 \\
(0.50)\end{array}$ & $\begin{array}{l}0.50 \\
(0.50)\end{array}$ & 1.00 \\
\hline Non-Graduate* & $\begin{array}{l}0.54 \\
(0.50)\end{array}$ & $\begin{array}{l}0.46 \\
(0.50)\end{array}$ & 1.00 \\
\hline Primary School* & $\begin{array}{l}0.57 \\
(0.50)\end{array}$ & $\begin{array}{l}0.43 \\
(0.50)\end{array}$ & 1.00 \\
\hline Middle School* & $\begin{array}{l}0.60 \\
(0.49)\end{array}$ & $\begin{array}{l}0.40 \\
(0.49)\end{array}$ & 1.00 \\
\hline High School* & $\begin{array}{l}0.62 \\
(0.48)\end{array}$ & $\begin{array}{l}0.38 \\
(0.48)\end{array}$ & 1.00 \\
\hline University+* & $\begin{array}{l}0.64 \\
(0.48)\end{array}$ & $\begin{array}{l}0.36 \\
(0.48)\end{array}$ & 1.00 \\
\hline \multicolumn{4}{|c|}{ Labor Market Status } \\
\hline Employed* & $\begin{array}{l}0.59 \\
(0.49)\end{array}$ & $\begin{array}{l}0.41 \\
(0.49)\end{array}$ & 1.00 \\
\hline Unemployed* & $\begin{array}{l}0.57 \\
(0.49)\end{array}$ & $\begin{array}{l}0.43 \\
(0.49)\end{array}$ & 1.00 \\
\hline Out of Labor Force* & $\begin{array}{l}0.57 \\
(0.49)\end{array}$ & $\begin{array}{l}0.43 \\
(0.49)\end{array}$ & 1.00 \\
\hline Log Household Income (TL) & $\begin{array}{l}6.93 \\
(0.61)\end{array}$ & $\begin{array}{l}6.89 \\
(0.62) \\
\end{array}$ & $\begin{array}{l}6.92 \\
(0.62)\end{array}$ \\
\hline Number of Observations in 2008 & 9665 & 2089 & 11754 \\
\hline Number of Observations in 2010 & 6074 & 5696 & 11770 \\
\hline Number of Observations in 2012 & 11199 & 11731 & 22930 \\
\hline Total Observations & 26938 & 19516 & 46454 \\
\hline
\end{tabular}

The average years of schooling is higher among drinkers (9.63 years) than among non- drinkers (6.14 years). The prevalence of alcohol consumption increases as level of education increases and it is highest among the university or higher graduates. Percentage of alcohol drinkers is higher among males than among females. Alcohol consumers are younger than the non-alcohol consumers and the urban residents consume more than the rural residents. Regarding the marital status, we note that the percentage of alcohol drinkers is higher among singles than the married and widowed/divorced. The fraction of alcohol 
drinkers among employed and unemployed are equal and significantly higher than that of the inactive. Lastly, household income is significantly higher among alcohol consumers.

\subsection{Fruit and Vegetable Consumption}

Fruit and vegetables are necessary for healthy life. Sufficient daily consumption of fruit and vegetables could prevent several kinds of diseases, such as cardiovascular diseases, certain cancers and diabetes (Hung et al. 2004). Hence, it is important to investigate the variation in fruit and vegetable consumption. We define an individual as a regular fruit and vegetable consumer if the individual reports that he/she consumes fruits, vegetables and/or their juice at least once a week. Table 3 presents the descriptive statistics for fruit and vegetable consumption.

We observe that years of schooling is higher among fruit and vegetable consumers than non-consumers. The prevalence of regular fruit and vegetable consumption is the highest among individuals who have university or higher degree compared to other education groups. The fruit and vegetable consumption are higher among males. Fruit and vegetable consumers are younger and urban residents consume more fruits and vegetables than rural ones. Singles consume more fruits and vegetables than the married and widowed/divorced. Fruit and vegetable consumption is similar among the employed, unemployed and inactive. Finally, household income is somewhat higher among the regular fruit and vegetable consumers.

\subsection{Exercise}

Regular physical activity is an important factor that improves the individual's health. It could prevent many diseases such as heart disease and stroke, high blood pressure, diabetes, obesity, back pain, osteoporosis, and can improve the psychological condition of the individual (Fletcher et al., 1996). Therefore, it is important to examine the variation in physical activity of the individuals. In THS we observe the respondent's frequency of exercise, divided into three categories: High level exercise (such as aerobic exercise or working in construction sector), medium level exercise (such as riding a bicycle or house work) and low-level exercise (such as walking). If the individual does not experience one of these activities at least 10 minutes in the reference week, then we assume that individual does not make regular physical activity. Table 4 presents the descriptive statistics for exercise.

Individuals who exercise regularly have higher years of schooling and prevalence of exercise is higher among university graduates and among males. Individuals who exercise regularly are younger. Urban residents exercise slightly more than the rural ones. Married and single individuals exercise more than the widowed/divorced. Employed people exercise more than the unemployed and the inactive. Finally, average household income is slightly higher among individuals who exercise regularly. 


\section{Table: 4}

Descriptive Statistics for Exercise

\begin{tabular}{|c|c|c|c|}
\hline Variable & Exercise Regularly & Not Exercise Regularly & Total \\
\hline Male* & $\begin{array}{l}0.71 \\
(0.45)\end{array}$ & $\begin{array}{l}0.29 \\
(0.45)\end{array}$ & 1.00 \\
\hline Female* & $\begin{array}{l}0.63 \\
(0.48)\end{array}$ & $\begin{array}{l}0.37 \\
(0.48)\end{array}$ & 1.00 \\
\hline Age (Years) & $\begin{array}{l}46.21 \\
(13.84)\end{array}$ & $\begin{array}{l}50.07 \\
(16.33)\end{array}$ & $\begin{array}{l}47.50 \\
(14.83)\end{array}$ \\
\hline Age-Squared & $\begin{array}{l}2326 \\
(1405)\end{array}$ & $\begin{array}{l}2774 \\
(1757)\end{array}$ & $\begin{array}{l}2475 \\
(1546)\end{array}$ \\
\hline Urban* & $\begin{array}{l}0.67 \\
(0.47)\end{array}$ & $\begin{array}{l}0.33 \\
(0.47)\end{array}$ & 1.00 \\
\hline Rural* & $\begin{array}{l}0.66 \\
(0.47)\end{array}$ & $\begin{array}{l}0.34 \\
(0.47)\end{array}$ & 1.00 \\
\hline Married* & $\begin{array}{ll} & \text { Marital Sta } \\
0.68 & \\
(0.47) & \end{array}$ & $\begin{array}{l}0.32 \\
(0.47)\end{array}$ & 1.00 \\
\hline Single* & $\begin{array}{l}0.69 \\
(0.46)\end{array}$ & $\begin{array}{l}0.31 \\
(0.46)\end{array}$ & 1.00 \\
\hline Widowed/Divorced* & $\begin{array}{l}0.54 \\
(0.50)\end{array}$ & $\begin{array}{l}0.46 \\
(0.50)\end{array}$ & 1.00 \\
\hline \multicolumn{4}{|c|}{ Education } \\
\hline Years of Schooling & $\begin{array}{l}7.00 \\
(4.36)\end{array}$ & $\begin{array}{l}5.78 \\
(4.48)\end{array}$ & $\begin{array}{l}6.60 \\
(4.44)\end{array}$ \\
\hline Years of Schooling-Squared & $\begin{array}{l}68.18 \\
(72.66)\end{array}$ & $\begin{array}{l}53.56 \\
(67.69)\end{array}$ & $\begin{array}{l}63.31 \\
(71.37)\end{array}$ \\
\hline Illiterate* & $\begin{array}{l}0.48 \\
(0.50)\end{array}$ & $\begin{array}{l}0.52 \\
(0.50)\end{array}$ & 1.00 \\
\hline Non-Graduate* & $\begin{array}{l}0.61 \\
(0.49)\end{array}$ & $\begin{array}{l}0.39 \\
(0.49)\end{array}$ & 1.00 \\
\hline Primary School* & $\begin{array}{l}0.68 \\
(0.46)\end{array}$ & $\begin{array}{l}0.32 \\
(0.46)\end{array}$ & 1.00 \\
\hline Middle School* & $\begin{array}{l}0.72 \\
(0.45)\end{array}$ & $\begin{array}{l}0.28 \\
(0.45)\end{array}$ & 1.00 \\
\hline High School* & $\begin{array}{l}0.72 \\
(0.45)\end{array}$ & $\begin{array}{l}0.28 \\
(0.45)\end{array}$ & 1.00 \\
\hline University+* & $\begin{array}{l}0.73 \\
(0.44)\end{array}$ & $\begin{array}{l}0.27 \\
(0.44)\end{array}$ & 1.00 \\
\hline \multicolumn{4}{|c|}{ Labor Market Status } \\
\hline Employed* & $\begin{array}{l}0.73 \\
(0.44)\end{array}$ & $\begin{array}{l}0.27 \\
(0.44)\end{array}$ & 1.00 \\
\hline Unemployed* & $\begin{array}{l}0.69 \\
(0.46)\end{array}$ & $\begin{array}{l}0.31 \\
(0.46)\end{array}$ & 1.00 \\
\hline Out of Labor Force* & $\begin{array}{l}0.62 \\
(0.49)\end{array}$ & $\begin{array}{l}0.38 \\
(0.49)\end{array}$ & 1.00 \\
\hline Log Household Income (TL) & $\begin{array}{l}6.95 \\
(0.61) \\
\end{array}$ & $\begin{array}{l}6.87 \\
(0.62)\end{array}$ & $\begin{array}{l}6.93 \\
(0.61) \\
\end{array}$ \\
\hline Number of Observations in 2008 & 7029 & 4078 & 11107 \\
\hline Number of Observations in 2010 & 7673 & 3118 & 10791 \\
\hline Number of Observations in 2012 & 14366 & 7341 & 21707 \\
\hline Total Observations & 29068 & 14537 & 43605 \\
\hline
\end{tabular}

\subsection{Obesity}

Obesity is an increasing health problem in Turkey. It is important to analyze the determinants of obesity as it is a major source of certain diseases such as cardiovascular diseases, diabetes, and joint problems (Stewart et al., 2009). OECD (2016) Health Data indicate that 24.5 percent of females and 15.3 per cent of males in Turkey were obese in 2014. World Bank (2008) reported that the adoption of Western diets high in refined carbohydrates, saturated fats and sugars and a more sedentary lifestyle are major contributors to the increase in overweight and chronic diseases in Turkey.

There are few studies that examine the determining factors of obesity in Turkey. These studies include Erem et al. (2004) and Hatemi et al. (2003). Erem et al. suggest that 
demographic factors such as marital status, number of births and household income as well as giving up smoking and alcohol consumption lead to higher BMI levels. On the contrary, they find that level of education, tobacco use, and higher physical activity is positively associated with lower BMI. Finally, they find that hypertension also promotes obesity. Hatemi et al. (2003) conclude that frequency of being obese or overweight is very high in Turkey and there is a positive relationship between higher BMI and blood pressure for both men and women. Yumuk (2005) concludes that men tend to be overweight more than women, however, women are more likely to be obese than men.

Table: 5

Descriptive Statistics for BMI

\begin{tabular}{|c|c|c|c|c|c|}
\hline Variable & $\begin{array}{c}\text { Underweight } \\
\text { (1) } \\
(\text { BMI }<18.5)\end{array}$ & $\begin{array}{c}\begin{array}{c}\text { Normal Weight } \\
(2)\end{array} \\
(18.5<=B M I<=24.99)\end{array}$ & $\begin{array}{c}\text { Overweight } \\
(3) \\
(25<=B M I<30)\end{array}$ & $\begin{array}{c}\text { Obese } \\
(4) \\
(B M I>=30)\end{array}$ & $\begin{array}{c}\text { Total } \\
\text { (5) }\end{array}$ \\
\hline Male* & $\begin{array}{l}0.01 \\
(0.10)\end{array}$ & $\begin{array}{l}0.37 \\
(0.48)\end{array}$ & $\begin{array}{l}0.45 \\
(0.50)\end{array}$ & $\begin{array}{l}0.17 \\
(0.38)\end{array}$ & 1.00 \\
\hline Female* & $\begin{array}{l}0.02 \\
(0.15)\end{array}$ & $\begin{array}{l}0.38 \\
(0.48)\end{array}$ & $\begin{array}{l}0.34 \\
(0.47)\end{array}$ & $\begin{array}{l}0.26 \\
(0.44)\end{array}$ & 1.00 \\
\hline Age (Years) & $\begin{array}{l}42.57 \\
(16.79)\end{array}$ & $\begin{array}{l}43.77 \\
(14.96)\end{array}$ & $\begin{array}{l}47.47 \\
(13.94)\end{array}$ & $\begin{array}{l}50.51 \\
(13.08)\end{array}$ & $\begin{array}{l}46.65 \\
(14.44)\end{array}$ \\
\hline Age-Squared & $\begin{array}{l}2093 \\
(1759)\end{array}$ & $\begin{array}{l}2139 \\
(1534)\end{array}$ & $\begin{array}{l}2447 \\
(1443)\end{array}$ & $\begin{array}{l}2722 \\
(1385)\end{array}$ & $\begin{array}{l}2385 \\
(1489)\end{array}$ \\
\hline Urban* & $\begin{array}{l}0.02 \\
(0.13)\end{array}$ & $\begin{array}{l}0.37 \\
(0.48)\end{array}$ & $\begin{array}{l}0.39 \\
(0.49)\end{array}$ & $\begin{array}{l}0.22 \\
(0.41)\end{array}$ & 1.00 \\
\hline Rural* & $\begin{array}{l}0.02 \\
(0.14)\end{array}$ & $\begin{array}{l}0.37 \\
(0.48) \\
\text { Marital Status }\end{array}$ & $\begin{array}{l}0.39 \\
(0.48)\end{array}$ & $\begin{array}{l}0.22 \\
(0.41)\end{array}$ & 1.00 \\
\hline Married* & $\begin{array}{l}0.01 \\
(0.12)\end{array}$ & $\begin{array}{l}0.35 \\
(0.48)\end{array}$ & $\begin{array}{l}0.41 \\
(0.49)\end{array}$ & $\begin{array}{l}0.23 \\
(0.42)\end{array}$ & 1.00 \\
\hline Single* & $\begin{array}{l}0.05 \\
(0.23)\end{array}$ & $\begin{array}{l}0.62 \\
(0.49)\end{array}$ & $\begin{array}{l}0.25 \\
(0.44)\end{array}$ & $\begin{array}{l}0.08 \\
(0.26)\end{array}$ & 1.00 \\
\hline Widowed/Divorced* & $\begin{array}{l}0.02 \\
(0.14)\end{array}$ & $\begin{array}{l}0.35 \\
(0.48) \\
\text { Education }\end{array}$ & $\begin{array}{l}0.35 \\
(0.48)\end{array}$ & $\begin{array}{l}0.28 \\
(0.45)\end{array}$ & 1.00 \\
\hline Years of Schooling & $\begin{array}{l}7.73 \\
(4.82)\end{array}$ & $\begin{array}{l}7.56 \\
(4.54)\end{array}$ & $\begin{array}{l}6.99 \\
(4.30)\end{array}$ & $\begin{array}{l}5.81 \\
(4.02)\end{array}$ & $\begin{array}{l}6.96 \\
(4.39)\end{array}$ \\
\hline Years of Schooling-Squared & $\begin{array}{l}82.87 \\
(80.44)\end{array}$ & $\begin{array}{l}77.77 \\
(76.78)\end{array}$ & $\begin{array}{l}67.39 \\
(71.75)\end{array}$ & $\begin{array}{l}49.98 \\
(61.99)\end{array}$ & $\begin{array}{l}67.78 \\
(72.65)\end{array}$ \\
\hline Illiterate* & $\begin{array}{l}0.02 \\
(0.14)\end{array}$ & $\begin{array}{l}0.34 \\
(0.47)\end{array}$ & $\begin{array}{l}0.34 \\
(0.48)\end{array}$ & $\begin{array}{l}0.30 \\
(0.46)\end{array}$ & 1.00 \\
\hline Non-Graduate* & $\begin{array}{l}0.02 \\
(0.12)\end{array}$ & $\begin{array}{l}0.31 \\
(0.46)\end{array}$ & $\begin{array}{l}0.37 \\
(0.48)\end{array}$ & $\begin{array}{l}0.30 \\
(0.46)\end{array}$ & 1.00 \\
\hline Primary School* & $\begin{array}{l}0.01 \\
(0.11)\end{array}$ & $\begin{array}{l}0.34 \\
(0.47)\end{array}$ & $\begin{array}{l}0.40 \\
(0.49\end{array}$ & $\begin{array}{l}0.25 \\
(0.43)\end{array}$ & 1.00 \\
\hline Middle School* & $\begin{array}{l}0.02 \\
(0.14)\end{array}$ & $\begin{array}{l}0.40 \\
(0.49)\end{array}$ & $\begin{array}{l}0.40 \\
(0.49)\end{array}$ & $\begin{array}{l}0.18 \\
(0.38)\end{array}$ & 1.00 \\
\hline High School* & $\begin{array}{l}0.02 \\
(0.14)\end{array}$ & $\begin{array}{l}0.44 \\
(0.50)\end{array}$ & $\begin{array}{l}0.39 \\
(0.49)\end{array}$ & $\begin{array}{l}0.15 \\
(0.36)\end{array}$ & 1.00 \\
\hline University $+*$ & $\begin{array}{l}0.02 \\
(0.16)\end{array}$ & $\begin{array}{l}0.47 \\
(0.50) \\
\text { bor Market Status }\end{array}$ & $\begin{array}{l}0.38 \\
(0.49)\end{array}$ & $\begin{array}{l}0.13 \\
(0.33)\end{array}$ & 1.00 \\
\hline Employed* & $\begin{array}{l}0.02 \\
(0.13)\end{array}$ & $\begin{array}{l}0.41 \\
(0.49)\end{array}$ & $\begin{array}{l}0.41 \\
(0.49)\end{array}$ & $\begin{array}{l}0.16 \\
(0.37)\end{array}$ & 1.00 \\
\hline Unemployed $*$ & $\begin{array}{l}0.03 \\
(0.17)\end{array}$ & $\begin{array}{l}0.53 \\
(0.50)\end{array}$ & $\begin{array}{l}0.35 \\
(0.48)\end{array}$ & $\begin{array}{l}0.09 \\
(0.28)\end{array}$ & 1.00 \\
\hline Out of Labor Force* & $\begin{array}{l}0.02 \\
(0.14)\end{array}$ & $\begin{array}{l}0.34 \\
(0.47)\end{array}$ & $\begin{array}{l}0.38 \\
(0.48)\end{array}$ & $\begin{array}{l}0.26 \\
(0.44)\end{array}$ & 1.00 \\
\hline Log Household Income (TL) & $\begin{array}{l}6.88 \\
(0.64)\end{array}$ & $\begin{array}{l}6.95 \\
(0.63)\end{array}$ & $\begin{array}{l}6.98 \\
(0.59) \\
\end{array}$ & $\begin{array}{l}6.95 \\
(0.59) \\
\end{array}$ & $\begin{array}{l}6.96 \\
(0.61)\end{array}$ \\
\hline Number of Observations in 2008 & 209 & 3998 & 3764 & 1943 & 9914 \\
\hline Number of Observations in 2010 & 201 & 3844 & 3928 & 2317 & 10290 \\
\hline Number of Observations in 2012 & 322 & 7570 & 8331 & 4647 & 20870 \\
\hline Total Observations & 732 & 15412 & 16023 & 8907 & 41074 \\
\hline
\end{tabular}


As mentioned in data definition section, we first calculate the individual's BMI by dividing his/her weight (in kilograms) by the square of self-reported height (in meter squares) then establish four weight categories based on WHO criteria. Table 5 presents the descriptive statistics for five different BMI groups as well as the statistics for BMI for the whole sample.

Accordingly, average years of schooling is lower among obese individuals. The prevalence of obesity is higher among illiterate and non-graduate individuals. Females are more obese than males and males are more overweight than females. Obese individuals are slightly older. There is no difference in the weight ranges of urban and rural residents. The occurrence of being overweight is higher among married and prevalence of obesity is higher among widowed/divorced individuals. Prevalence of being obese is higher among inactive individuals. Lastly, we observe that household income is slightly higher among overweight individuals.

\section{Empirical Specification}

In the empirical specification, the health outputs are health related behaviors and obesity. The health behaviors are smoking, alcohol consumption, fruit and vegetable consumption and exercise. We investigate the effect of various inputs on each of the health behaviors separately in six different models. Formally, we can write our health function as follows:

$$
\mathrm{H}=\mathrm{f}(\mathrm{E}, \mathrm{G}, \mathrm{A}, \mathrm{P}, \mathrm{M}, \mathrm{L}, \mathrm{I})
$$

where $\mathrm{H}$ refers to a health behavior or obesity. It is a binary variable as defined in the data section. $\mathrm{H}$ is a function of education $(\mathrm{E})$, gender $(\mathrm{G})$, age $(\mathrm{A})$, the place where the individual lives (P), marital status (M), labor market status (L) and logarithm of household income (I).

Specifically, we estimate the following probit model:

$$
\begin{aligned}
& P(H=1)=\phi\left(\beta_{0}+\beta_{1} E_{i}+\beta_{2} E_{i}^{2}+\beta_{3} G_{i}+\beta_{4} A_{i}+\beta_{5} A_{i}^{2}+\beta_{6} P_{i}+\beta_{7} M_{i}+\beta_{8} L_{i}+\beta_{9} I_{i}+\right. \\
& \left.\beta_{10} m_{i}\right)
\end{aligned}
$$

The marginal effects are calculated in the following manner:

$$
\frac{\partial P\left(H=1 \mid X_{i}\right)}{\partial X_{i j}}=\phi^{\prime}\left(X_{i}^{\prime} \beta\right) \beta_{j}
$$

where $\mathrm{X}$ refers to the vector of control variables and $\phi$ refers to the standard normal cumulative distribution function.

Grossman (2004) states that formal schooling is the most important determinant of health regardless of the measure of the health used. Such as mortality, morbidity, SAH or psychological indicators of health. In order to circumvent the problem of individuals who do not yet complete their schooling, the sample is restricted to individuals who are above 25 
years of age in our analysis, since most individuals complete their schooling around that age in Turkey.

Two different models are specified with regards to education. In the first specification education is specified as a linear and quadratic term in years of schooling, defined in equation (2). In the second specification education is represented by six dummy variables for different levels of education completed as discussed in the data section. Illiterates is the base category. In this new specification, we introduce education level dummies instead of $\mathrm{E}_{\mathrm{i}}$ and $\mathrm{E}_{\mathrm{i}}^{2}$ in equation (2).

The theoretical framework suggests that health behaviors that improve the individual's health (fruit and vegetable consumption, exercise are increasing in education, whereas health behaviors that weakens the individual's health (smoking, alcohol consumption, being underweight, overweight and obese) are decreasing in education. Since health is a capital that depreciates over time, age is included in the model. Both Grossman (1972) and Bolin (2011) indicate that rate of depreciation decreases with education level and increases with age. Therefore, other things being equal we expect a risky health behavior to increase with age.

Gender, marital status and urban/rural location are included to explain the variation in health behaviors. These covariates are widely empirically examined. The literature suggest that females have better health status than males (Case \& Paxson, 2005; Fuchs, 2004). Hence, the gender dummy $G$ takes the value of 1 if the individual is male, and 0 if female. Reijneveld (2002) conclude that people living in more-favored places have better health statuses than people living in less-favored places. Therefore, a location variable, $\mathrm{P}$ is included. It takes the value of 1 if the location is urban and zero if rural. The literature suggests that in general, married individuals are healthier than those who are not married. According to Fuchs (2004) having a spouse makes positive contribution to an individual' health. Therefore, marital status (M) is also included in our analysis. We define three dummy variables. Married takes the value of 1 if the individual is married and 0 otherwise. Single takes the value of 1 if the individual is not married. Widowed/divorced takes the value of one if the spouse is diseased, divorced or separated. Widowed/divorced is the base category.

Individual's employment status is included as a proxy for the socioeconomic status (SES). Employed individuals have more social networks than the unemployed or the inactive. Cutler et al. (2011) state that low SES in occupation leads to psychosocial stress because of subordination feelings and lack of control which causes deterioration in health. Hence, we expect that the occurrence of risky health behaviors decreases if the individual is employed.

The THS data set does not include information on individual income however household income is available which we include as a proxy for the individual income. Higher income levels lead to better health status. Therefore, we expect risky health behavior to decrease as household income increases. Finally, we include dummy variables for the survey 
years of 2010 and 2012 in our pooled sample where 2008 is the base (2012 for smoking where 2010 is the base).

\section{Empirical Results}

The probit models are estimated by maximum likelihood estimation (MLE). One should be careful in interpreting our estimated coefficients in the sense that they do not provide a causal relationship; rather they show the controlled associations between each control variable and individuals' health behaviors and obesity.

We present the estimation results for each of the health behaviors and obesity in a separate section. We estimate seven different probit models where we introduce additional regressors gradually to the baseline Model (1) which includes individual's completed years of schooling. The second model includes years of schooling and square of years of schooling. The third model adds gender dummy. The fourth model adds age, age squared and rural/urban location indicator. The fifth model adds marital status indicators. The sixth model adds labor market status indicators. Finally, the last model adds household income. Here, our objective is to see whether the magnitude and significance of years of schooling variable is affected by the gradual addition of other determining factors to the model. The magnitude of the years of schooling is slightly reduced as additional variables are included in the model but its significance never changes, which is consistent with the findings of Cutler and Llearas-Muney (2010). The same models are also estimated for each of the health behaviors by using five dummy variables indicating different education levels instead of years of education. This is a flexible specification suggested by the specification with years of schooling and its square. With this specification we first would like to see if there would be a change in the interpretation of our findings. We observe that the neither the sign nor the significance of other variables do not change. Our second objective is to see how the health behaviors and obesity vary among different education groups. Indeed, unlike the previous studies, THS data enable us to see the variation of health behaviors and obesity among different education levels.

\subsection{Smoking}

Table 6 reports the marginal effects from probit estimation results. We observe probability of smoking increases by 3.84 percentage points when schooling increases by a year. The positive association between years of schooling and smoking in our study contradicts with previous studies such as Cutler and Learas-Muney (2010), Kenkel (1991) and Lantz et al. (2001). They all find a negative and significant relationship between years of schooling and smoking in the USA and UK which are developed countries unlike Turkey which is a middle-income developing country. For this reason, the relationship between education and smoking may differ in Turkey from that in the developed countries. Indeed, the coefficient estimate of the years of schooling squared indicate that smoking and years of schooling has an inverted U-shaped relationship. This implies that the probability of smoking decreases among the highly educated. 
Table: 6

\begin{tabular}{|c|c|c|c|c|c|c|c|}
\hline VARIABLES & (1) & (2) & (3) & (4) & (5) & (6) & (7) \\
\hline Years of Schooling & $\begin{array}{l}1.60^{* * * *} \\
(0.0489)\end{array}$ & $\begin{array}{l}7.70^{* * * *} \\
(0.200)\end{array}$ & $\begin{array}{l}6.05^{* * * *} \\
(0.202)\end{array}$ & $\begin{array}{l}3.65 * * * \\
(0.211)\end{array}$ & $\begin{array}{l}3.74 * * * \\
(0.211)\end{array}$ & $\begin{array}{l}3.81^{* * * *} \\
(0.211)\end{array}$ & $\begin{array}{l}3.76 * * * \\
(0.212)\end{array}$ \\
\hline Years of Schooling Square & & $\begin{array}{c}-0.380 * * * \\
(0.0119)\end{array}$ & $\begin{array}{c}-0.307 * * * * \\
(0.0118)\end{array}$ & $\begin{array}{c}-0.208^{* * * * *} \\
(0.012)\end{array}$ & $\begin{array}{c}-0.212 * * * \\
(0.012)\end{array}$ & $\begin{array}{c}-0.221 * * * * \\
(0.012)\end{array}$ & $\begin{array}{c}-0.220 * * * * \\
(0.0121)\end{array}$ \\
\hline Male & & & $\begin{array}{c}20.6^{* * * *} \\
(0.433)\end{array}$ & $\begin{array}{l}23.0 * * * \\
(0.427)\end{array}$ & $\begin{array}{c}24.0 * * * \\
(0.432)\end{array}$ & $\begin{array}{l}21.0^{* * * *} \\
(0.531)\end{array}$ & $\begin{array}{l}21.2 * * * \\
(0.537)\end{array}$ \\
\hline $\operatorname{Age}\left(x_{10}^{-1}\right)$ & & & & $\begin{array}{c}8.63 * * * \\
(1.18)\end{array}$ & $\begin{array}{c}9.25 * * * \\
(1.23)\end{array}$ & $\begin{array}{c}8.47^{* * * *} \\
(1.20)\end{array}$ & $\begin{array}{c}8.47 * * * \\
(1.21)\end{array}$ \\
\hline Age Square $\left(\mathrm{x}^{10} 0^{-3}\right)$ & & & & $\begin{array}{l}-14.0^{* * * *} \\
(1.22)\end{array}$ & $\begin{array}{l}-15.3^{* * * *} \\
(1.26)\end{array}$ & $\begin{array}{l}-13.7 * * * * \\
(1.24)\end{array}$ & $\begin{array}{l}-13.8^{* * * *} \\
(1.25)\end{array}$ \\
\hline Urban & & & & $\begin{array}{c}5.42 * * * \\
(0.529) \\
\end{array}$ & $\begin{array}{l}5.13 * * * \\
(0.528)\end{array}$ & $\begin{array}{l}5.56 * * * \\
(0.531)\end{array}$ & $\begin{array}{l}5.56 * * * \\
(0.548)\end{array}$ \\
\hline \multicolumn{8}{|c|}{ Marital Status } \\
\hline Married & & & & & $\begin{array}{c}-11.3 * * * * \\
(0.864)\end{array}$ & $\begin{array}{c}-10.5 * * * * \\
(0.864)\end{array}$ & $\begin{array}{c}-10.7 \text { **** } \\
(0.871)\end{array}$ \\
\hline Single & & & & & $\begin{array}{c}-11.9 * * * \\
(1.21) \\
\end{array}$ & $\begin{array}{c}-11.8 * * * * \\
(1.21) \\
\end{array}$ & $\begin{array}{c}-12.1^{* * * *} \\
(1.22)\end{array}$ \\
\hline \multicolumn{8}{|c|}{ Labor Force Status } \\
\hline Employed & & & & & & $\begin{array}{l}5.16^{* * * *} \\
(0.588)\end{array}$ & $\begin{array}{l}5.02 * * * \\
(0.593)\end{array}$ \\
\hline Unemployed & & & & & & $\begin{array}{c}10.8^{* * * *} \\
(1.31)\end{array}$ & $\begin{array}{c}10.7 * * * \\
(1.34)\end{array}$ \\
\hline Log Household Income & & & & & & & $\begin{array}{c}0.429 \\
(0.466)\end{array}$ \\
\hline Dummy12 & $\begin{array}{c}-2.01 * * * * \\
(0.503)\end{array}$ & $\begin{array}{c}-2.20^{* * * *} \\
(0.498)\end{array}$ & $\begin{array}{c}-2.38^{* * * *} \\
(0.482)\end{array}$ & $\begin{array}{c}-2.22 * * * * \\
(0.473)\end{array}$ & $\begin{array}{l}-2.26^{* * * *} \\
(0.472)\end{array}$ & $\begin{array}{c}-2.20^{* * * *} \\
(0.471)\end{array}$ & $\begin{array}{c}-2.27 * * * * \\
(0.481)\end{array}$ \\
\hline $\begin{array}{l}\text { Pseudo R2 } \\
\text { (-) Log Likelihoed }\end{array}$ & 0.02 & $\begin{array}{c}0.05 \\
19798\end{array}$ & $\begin{array}{c}0.09 \\
18802\end{array}$ & 0.12 & 0.13 & $\begin{array}{c}0.13 \\
18081\end{array}$ & $\begin{array}{c}0.13 \\
17894\end{array}$ \\
\hline $\begin{array}{l}\text { (-) Log Likelihood } \\
\text { Observations }\end{array}$ & $\begin{array}{c}20317 \\
34,716\end{array}$ & $\begin{array}{r}19798 \\
34,716 \\
\end{array}$ & $\begin{array}{c}18802 \\
34,716\end{array}$ & $\begin{array}{r}18219 \\
34,716\end{array}$ & $\begin{array}{r}18137 \\
34,716\end{array}$ & $\begin{array}{r}18081 \\
34,716\end{array}$ & $\begin{array}{r}1 / 894 \\
34,350\end{array}$ \\
\hline
\end{tabular}

Table 7 reports the marginal effects (in percentages) (see also Figure 1) of probit estimation where education dummies for different levels of education are used in place of years of schooling. We again find a positive relationship between smoking and education which declines over education levels. The marginal effects in Table 7 suggests that if the individual is middle school graduate, then his/her probability of being smoker increases by 17.27 per cent when we control gender, age, place of residence, marital status, labor market status and household income. This percentage decreases to 14.63 per cent for high school graduates and 5.42 per cent for the individuals with univeresity or higher degree. The average marginal effect of education on probability of smoking clearly decreases at higher levels of education; and this supports the inverted U-shaped relationship between education and probability of being smoker. Hence, we conclude that individuals who have college degree are better informed about adverse health effects of smoking than the less educated.

8 For all the tables in Section 5:

Notes:

(1) $* * *, * *$ and $*$ indicate levels of significance at 1, 5 and $10 \%$.

(2) Robust standard errors are shown in paranthesis.

(3) Marginal effects are computed at the means of the variables. 
Table: 7

Marginal Effects from Probit Estimation for Smoking with Education Levels (\%) ${ }^{9}$

\begin{tabular}{lllllll}
\hline Variable & $(1)$ & $(2)$ & $(3)$ & $(4)$ & $(5)$ & $(6)$ \\
\hline & & & & Education & & \\
Non-Graduate & $13.2^{* * *}$ & $8.50^{* * *}$ & $6.27^{* * *}$ & $6.75^{* * *}$ & $6.84^{* * *}$ & $6.66^{* * * *}$ \\
& $(1.39)$ & $(1.34)$ & $(1.33)$ & $(1.32)$ & $(1.31)$ & $(1.32)$ \\
Primary School & $27.6^{* * *}$ & $20.16^{* * *}$ & $10.98^{* * *}$ & $11.71^{* * *}$ & $11.67^{* * * *}$ & $11.50^{* * *}$ \\
& $(0.93)$ & $(0.91)$ & $(0.94)$ & $(0.95)$ & $(0.94)$ & $(0.95)$ \\
Middle School & $39.5^{* * *}$ & $29.45^{* * *}$ & $17.20^{* * *}$ & $17.81^{* * *}$ & $17.62^{* * *}$ & $17.27^{* * *}$ \\
& $(1.10)$ & $(1.09)$ & $(1.14)$ & $(1.14)$ & $(1.14)$ & $(1.16)$ \\
High School & $37.3^{* * *}$ & $28.08^{* * *}$ & $14.74^{* * *}$ & $15.34^{* * *}$ & $14.99^{* * *}$ & $14.63^{* * *}$ \\
& $(1.01)$ & $(1.01)$ & $(1.08)$ & $(1.08)$ & $(1.08)$ & $(1.12)$ \\
University+ & $29.1^{* * *}$ & $19.47^{* * *}$ & $6.29^{* * *}$ & $7.11^{* * *}$ & $5.89^{* * *}$ & $5.42^{* * * *}$ \\
& $(1.07)$ & $(1.07)$ & $(1.14)$ & $(1.14)$ & $(1.15)$ & $(1.22)$ \\
Pseudo R2 & 0.04 & 0.10 & 0.12 & 0.13 & 0.13 & 0.13 \\
$(-)$ Log-Likelihood & 19787 & 18791 & 18227 & 18152 & 18091 & 17905 \\
\hline $\mathbf{N}$ & 34716 & 34716 & 34716 & 34716 & 34716 & 34350 \\
\hline
\end{tabular}

Figure: 1

Marginal Effects (x100) on Probability of Smoking by Education Level

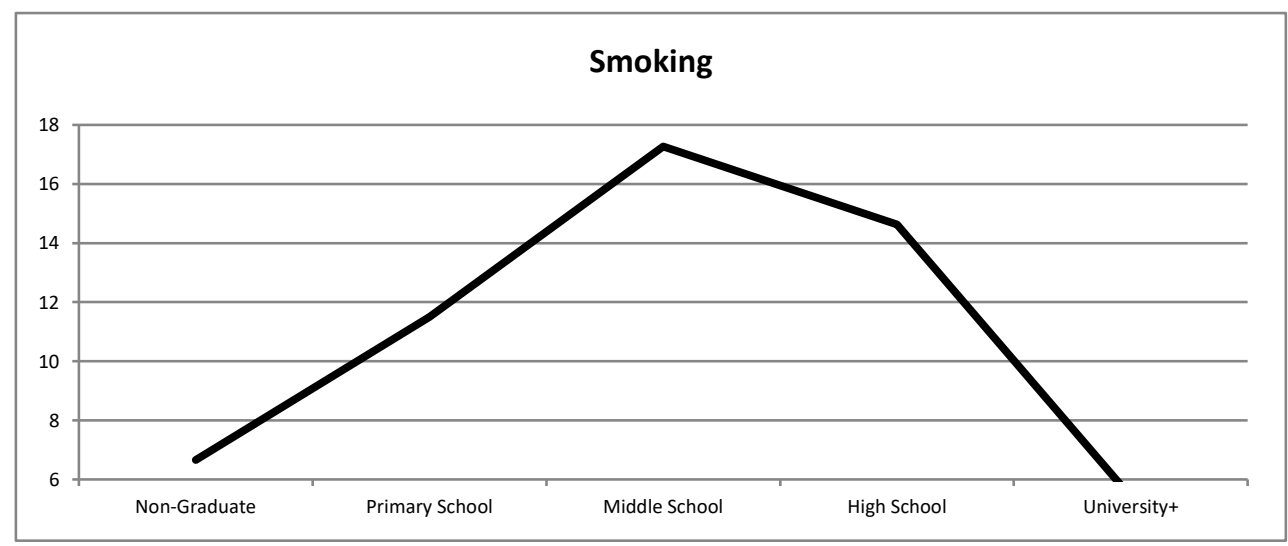

Source: THS 2010 and 2012 pooled data set.

The results for the other covariates are similar in Tables 6 and 7. Therefore, we comment only on the estimates in Table 7 briefly. Men are more likely to smoke than women. Smoking and age have concave relationship. Urban residents tend to smoke more than the rural residents. Married and single individuals are less likely to smoke than the widowed/divorced. Further, we note that the probability smoking for an unemployed (10.99 per cent) is twice as large as that for an employed person (5.36 per cent) relative to inactive.

9 For Tables 7, 9, 11,13, 15:

The Models (1), (2), (3), (4), (5) and (6) in these tables include additional regressors similar to the Models (1) and(2), (3), (4),(5), (6) and (7) respectively in Tables 6, 8,10,12 and 14. The results of the second specification for each health behavior and obesity are qualitatively similar to the results of the previous specification, where we use non-linear years of schooling variable instead of education dummies. They are not reported to save space. They are available in Tansel and Karaoğlan (2014). 
These results may be due to the fact that employment and unemployment may be stressful labor market states. Finally, household income does not significantly affect smoking behavior. Cutler and Llearas-Muney (2010) also include labor market status along with other main covariates. They suggest that the inclusion of labor market status variables reduces the education coefficient by 10 percentage points. Comparing Model (1) and Model (6) in Table 7 we note that inclusion of all other covariates reduces the coefficient of years of schooling almost by half.

\subsection{Alcohol Consumption}

Table 8 presents the marginal effects from probit estimation results. Our results indicate that there is a positive relationship between education level and alcohol consumption. We find that the probability of alcohol consumption increases by 2.36 percentage points when schooling increases by one year.

Table: 8

Marginal Effects from Probit Estimation for Alcohol Consumption with Years of Schooling (\%)

\begin{tabular}{|c|c|c|c|c|c|c|c|}
\hline VARIABLES & (1) & (2) & (3) & (4) & (5) & $(6)$ & (7) \\
\hline Years of Schooling & $\begin{array}{c}0.296 * * * \\
(0.0154)\end{array}$ & $\begin{array}{c}0.879^{* * * *} \\
(0.071)\end{array}$ & $\begin{array}{l}0.572 * * * \\
(0.0747)\end{array}$ & $\begin{array}{c}0.571 * * * \\
(0.0826)\end{array}$ & $\begin{array}{c}0.580^{* * * *} \\
(0.0818)\end{array}$ & $\begin{array}{c}0.591 * * * \\
(0.0822)\end{array}$ & $\begin{array}{c}0.528 * * * \\
(0.0835)\end{array}$ \\
\hline Years of Schooling Square & & $\begin{array}{c}-0.0332 * * * \\
(0.0039)\end{array}$ & $\begin{array}{c}-0.0194 * * * \\
(0.00406)\end{array}$ & $\begin{array}{c}-0.0187 * * * \\
(0.00434)\end{array}$ & $\begin{array}{c}-0.0196^{* * * *} \\
(0.00431)\end{array}$ & $\begin{array}{c}-0.0202 * * * \\
(0.00433)\end{array}$ & $\begin{array}{c}-0.0213 * * * \\
(0.00438)\end{array}$ \\
\hline Male & & & $\begin{array}{c}4.86^{* * * *} \\
(0.224)\end{array}$ & $\begin{array}{c}4.77 * * * * \\
(0.223)\end{array}$ & $\begin{array}{c}4.91 * * * \\
(0.230)\end{array}$ & $\begin{array}{c}4.74 * * * \\
(0.251)\end{array}$ & $\begin{array}{c}4.89 * * * \\
(0.255)\end{array}$ \\
\hline $\operatorname{Age}\left(\mathbf{x 1 0}^{-1}\right)$ & & & & $\begin{array}{c}2.57 * * * \\
(0.346)\end{array}$ & $\begin{array}{c}3.43 * * * \\
(0.378)\end{array}$ & $\begin{array}{l}3.40 * * * \\
(0.375)\end{array}$ & $\begin{array}{l}3.18 * * * \\
(0.382)\end{array}$ \\
\hline Age Square $\left(\mathbf{x 1 0}^{-3}\right)$ & & & & $\begin{array}{c}-2.45^{* * * *} \\
(0.346)\end{array}$ & $\begin{array}{c}-3.24 * * * \\
(0.375)\end{array}$ & $\begin{array}{c}-3.14 * * * \\
(0.374)\end{array}$ & $\begin{array}{c}-2.99 * * * \\
(0.381)\end{array}$ \\
\hline Urban & & & & $\begin{array}{l}0.0766 \\
(0.167) \\
\end{array}$ & $\begin{array}{l}0.0719 \\
(0.167) \\
\end{array}$ & $\begin{array}{l}0.0894 \\
(0.168) \\
\end{array}$ & $\begin{array}{l}-0.233 \\
(0.172) \\
\end{array}$ \\
\hline \multicolumn{8}{|c|}{ Marital Status } \\
\hline $\begin{array}{l}\text { Married } \\
\text { Single }\end{array}$ & & & & & $\begin{array}{c}-1.42 * * * * \\
(0.298) \\
0.0224 \\
(0.377)\end{array}$ & $\begin{array}{c}-1.38 * * * * \\
(0.298) \\
0.0431 \\
(0.379)\end{array}$ & $\begin{array}{c}-1.49 * * * * \\
(0.303) \\
-0.161 \\
(0.388)\end{array}$ \\
\hline \multicolumn{8}{|c|}{ Labor Force Status } \\
\hline Employed & & & & & & $\begin{array}{l}0.347 * \\
(0.197)\end{array}$ & $\begin{array}{c}0.198 \\
(0.199)\end{array}$ \\
\hline Unemployed & & & & & & $\begin{array}{c}0.749 * * \\
(0.365)\end{array}$ & $\begin{array}{l}1.12 * * * \\
(0.375)\end{array}$ \\
\hline Log Household Income & & & & & & & $\begin{array}{l}1.26 * * * \\
(0.154)\end{array}$ \\
\hline Dummy10 & $\begin{array}{c}0.452 * * \\
(0.187)\end{array}$ & $\begin{array}{c}0.479 * * \\
(0.187)\end{array}$ & $\begin{array}{c}0.605 * * * \\
(0.185)\end{array}$ & $\begin{array}{c}0.571^{* * * *} \\
(0.185)\end{array}$ & $\begin{array}{c}0.548^{* * * *} \\
(0.185)\end{array}$ & $\begin{array}{c}0.548^{* * * *} \\
(0.185)\end{array}$ & $\begin{array}{c}0.390^{* * *} \\
(0.187)\end{array}$ \\
\hline Dummy12 & $\begin{array}{c}-0.662 * * * \\
(0.175)\end{array}$ & $\begin{array}{c}-0.656 * * * \\
(0.175)\end{array}$ & $\begin{array}{c}-0.605 * * * \\
(0.172)\end{array}$ & $\begin{array}{c}-0.640 * * * \\
(0.172)\end{array}$ & $\begin{array}{c}-0.679 * * * \\
(0.172)\end{array}$ & $\begin{array}{c}-0.677 * * * \\
(0.172)\end{array}$ & $\begin{array}{c}-1.05 * * * \\
(0.181)\end{array}$ \\
\hline $\begin{array}{l}\text { Pseudo R2 } \\
\text { (-)Log Likelihood }\end{array}$ & $\begin{array}{l}0.04 \\
5000\end{array}$ & $\begin{array}{l}0.05 \\
4964\end{array}$ & $\begin{array}{l}0.13 \\
4519\end{array}$ & $\begin{array}{l}0.14 \\
4486\end{array}$ & $\begin{array}{l}0.14 \\
4460\end{array}$ & $\begin{array}{l}0.14 \\
4457\end{array}$ & $\begin{array}{l}0.15 \\
4380\end{array}$ \\
\hline Observations & 46,493 & 46,493 & 46,493 & 46,493 & 46,493 & 46,493 & 46,024 \\
\hline
\end{tabular}

We replicate our model by adding education dummies in place of years of schooling. The marginal effects (in percentages) (see also Figure 2) from this regression are reported in Table 9. Table 9 shows that the probability of alcohol consumption increases with education level. It increases by 5.64 percentage points for non-graduates, 12.59 percentage points for primary school graduates 16.91 percentage points for middle school graduates by 17.95 percentage points for high school graduates and 20.91 percentage points for the 
individuals with university or higher degree, compared to illiterates. This result can be attributed to two facts: First, highly educated people participate in social activities more than the low educated due to their larger social networks and they tend to consume more alcohol during the social activities. Second, as Kenkel (1991) suggests, more educated people may know that some drink is good for health, hence they drink more than the others.

Table: 9

Marginal Effects from Probit Estimation for Alcohol Consumption with Education

\begin{tabular}{|c|c|c|c|c|c|c|}
\hline Variable & (1) & (2) & (3) & (4) & (5) & (6) \\
\hline & \multicolumn{6}{|c|}{ Education } \\
\hline \multirow[t]{2}{*}{ Non-Graduate } & $2.04 * * *$ & $5.85^{* * * *}$ & $5.58 * * *$ & $5.91 * * *$ & $5.98 * * *$ & $5.64 * * *$ \\
\hline & $(0.716)$ & $(1.37)$ & $(1.36)$ & $(1.35)$ & $(1.35)$ & $(1.35)$ \\
\hline \multirow[t]{2}{*}{ Primary School } & $4.75^{* * * *}$ & $15.57 * * *$ & $13.31 * * *$ & $13.78 * * *$ & $13.82 * * *$ & $12.59 * * *$ \\
\hline & $(0.549)$ & $(1.05)$ & $(1.06)$ & $(1.06)$ & $(1.06)$ & $(1.06)$ \\
\hline \multirow[t]{2}{*}{ Middle School } & $6.31 * * *$ & $21.23 * * *$ & $18.62 * * *$ & $18.92 * * *$ & $18.91^{* * * *}$ & $16.91 * * *$ \\
\hline & $(0.580)$ & $(1.11)$ & $(1.13)$ & $(1.13)$ & $(1.13)$ & $(1.14)$ \\
\hline \multirow[t]{2}{*}{ High School } & $6.03 * * *$ & $23.25 * * *$ & $20.46 * * *$ & $20.72 * * *$ & $20.62 * * *$ & $17.95^{* * *}$ \\
\hline & $(0.567)$ & $(1.08)$ & $(1.11)$ & $(1.11)$ & $(1.11)$ & $(1.12)$ \\
\hline \multirow[t]{2}{*}{ University+ } & $6.98 * * *$ & $28.21 * * *$ & $25.43 * * *$ & $25.60 * * *$ & $24.83^{* * * *}$ & $20.91 * *$ \\
\hline & $(0.571)$ & $(1.08)$ & $(1.11)$ & $(1.11)$ & $(1.11)$ & $(1.14)$ \\
\hline Pseudo R2 & 0.05 & 0.16 & 0.16 & 0.17 & 0.17 & 0.18 \\
\hline (-) Log-Likelihood & 4948 & 13961 & 13867 & 13818 & 13746 & 13523 \\
\hline $\mathbf{N}$ & 46493 & 46493 & 46493 & 46493 & 46493 & 46024 \\
\hline
\end{tabular}

Figure: 2

Marginal Effects (x100) on Probability of Alcohol Consumption by Education Level

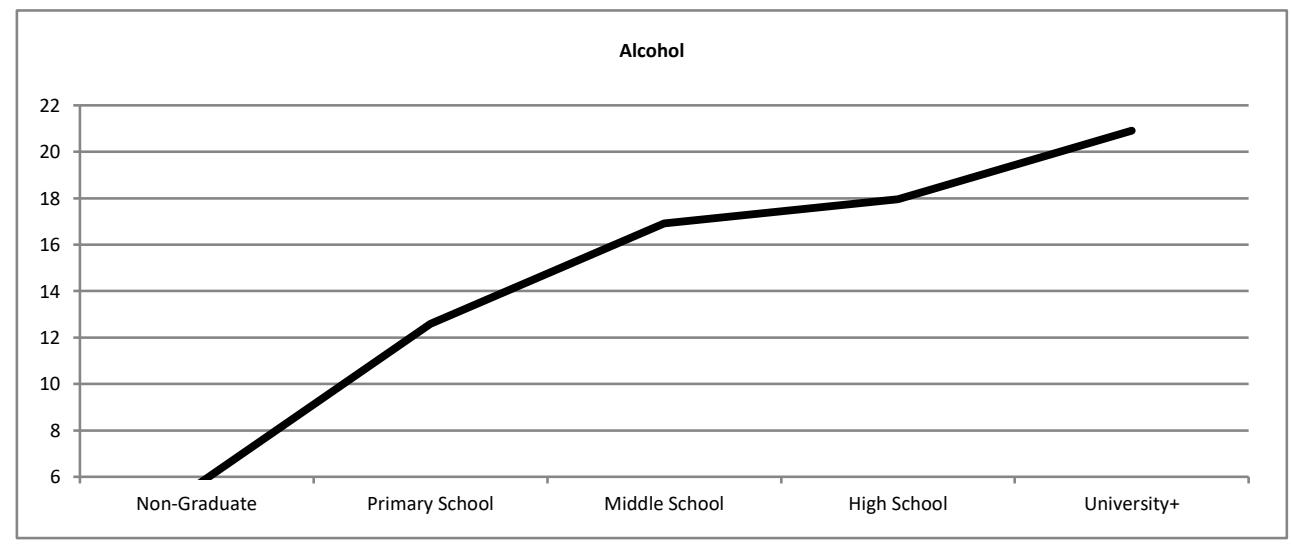

Source: THS 2008, 2010 and 2012 pooled data set.

We next consider the rest of the covariates. We see that males tend to consume more alcohol than females. Like in the case of smoking, the relationship between alcohol consumption and age is an inverted U-shaped. Alcohol consumption increases with age and roughly at age 48 alcohol consumption reaches a maximum after which it starts to decrease. The urban dwellers consume significantly more alcohol than the rural ones albeit it loses its significance when we control for income. The probability of alcohol consumption of married and single people are significantly less than that of widowed/divorced. Moreover, being in labor force also positively and significantly affects the probability of alcohol consumption. 
The probability of alcohol consumption increases by approximately 4 percentage points and 6 percentage points for the employed and unemployed respectively compared to an inactive person. This finding may again be attributed to larger social networks for the employed and the anxiety/stress for the unemployed. Finally, we find that an increase in log of household income leads to 3.90 percentage point's increase in probability of alcohol consumption.

In short, our results are consistent with Kenkel (1991) as well as Ettner (1996) who suggest higher probability of light drinking among higher socioeconomic groups. However, Cutler and Llearas-Muney (2010) find a negative association between probability of being heavy alcohol drinker and education. It is important to note that the number of heavy drinkers in our data set is very small for a separate analysis. Thus; our results mostly explain the variations in light alcohol consumption by education and other determinants like Kenkel and Ettner.

\subsection{Fruit and Vegetable Consumption}

Table 10 presents the marginal effects (in percentages) from probit estimation results. We find that fruit and vegetable consumption is positively and significantly associated with education level. We observe that the probability of fruit and vegetable consumption increases by 1.42 percentage points when years of schooling increase by a year.

Table: 10

Marginal Effects from Probit Estimation for Fruit and Vegetable Consumption with Years of Schooling

\begin{tabular}{|c|c|c|c|c|c|c|c|}
\hline VARIABLES & (1) & $(2)$ & (3) & (4) & (5) & (6) & $(7)$ \\
\hline \multirow[t]{2}{*}{ Years of Schooling } & $1.05 * * *$ & $1.86 * * *$ & $1.87 * * *$ & $1.76^{* * * *}$ & $1.78 * * *$ & $1.74 * * *$ & $1.41 * * *$ \\
\hline & $(0.0491)$ & $(0.16)$ & $(0.163)$ & $(0.177)$ & $(0.177)$ & $(0.178)$ & $(0.180)$ \\
\hline \multirow[t]{2}{*}{ Years of Schooling Square } & & $-0.0533 * * *$ & $-0.0538 * * *$ & $-0.0551 * * *$ & $-0.0583 * * *$ & $-0.0535 * * *$ & $-0.0572 * * *$ \\
\hline & & $(0.0101)$ & $(0.0102)$ & $(0.0106)$ & $(0.0106)$ & $(0.0107)$ & $(0.0108)$ \\
\hline \multirow[t]{2}{*}{ Male } & & & -0.16 & 0.136 & -0.0812 & $1.27 * *$ & $2.00^{* * *}$ \\
\hline & & & $(0.456)$ & $(0.462)$ & $(0.471)$ & $(0.547)$ & $(0.551)$ \\
\hline \multirow[t]{2}{*}{$\operatorname{Age}\left(\mathrm{x}_{10} 0^{-1}\right)$} & & & & $-3.29 * * *$ & $-2.40^{* *}$ & $-2.34 * *$ & $-3.53 * * *$ \\
\hline & & & & $(0.912)$ & $(0.951)$ & $(0.951)$ & $(0.96)$ \\
\hline \multirow[t]{2}{*}{$\operatorname{Age} \operatorname{Square}\left(\mathbf{x 1 0}^{-3}\right)$} & & & & $3.27 * * *$ & $2.64 * * *$ & $2.26^{* *}$ & $3.19 * * *$ \\
\hline & & & & $(0.88)$ & $(0.917)$ & $(0.920)$ & $(0.927)$ \\
\hline \multirow[t]{2}{*}{ Urban } & & & & $4.64 * * *$ & $4.71^{* * *}$ & $4.47 * * *$ & $3.00 * * *$ \\
\hline & & & & $(0.499)$ & $(0.50)$ & $(0.504)$ & $(0.520)$ \\
\hline \multicolumn{8}{|c|}{ Marital Status } \\
\hline \multirow[t]{2}{*}{ Married } & & & & & 1.08 & 0.679 & -0.194 \\
\hline & & & & & $(0.791)$ & $(0.794)$ & $(0.799)$ \\
\hline \multirow[t]{2}{*}{ Single } & & & & & $4.78 * * *$ & $4.87 * * *$ & $3.83^{* * *}$ \\
\hline & & & & & $(1.17)$ & $(1.18)$ & $(1.19)$ \\
\hline \multicolumn{8}{|c|}{ Labor Force Status } \\
\hline \multirow[t]{2}{*}{ Employed } & & & & & & $-2.44 * * *$ & $-3.05 * * *$ \\
\hline & & & & & & $(0.579)$ & $(0.582)$ \\
\hline \multirow[t]{2}{*}{ Unemployed } & & & & & & $-6.37 * * *$ & $-4.58 * * *$ \\
\hline & & & & & & $(1.36)$ & $(1.38)$ \\
\hline \multirow[t]{2}{*}{ Log Household Income } & & & & & & & $5.88 * * *$ \\
\hline & & & & & & & $(0.447)$ \\
\hline \multirow[t]{2}{*}{ Dummy10 } & $-32.2 * * *$ & $-32.2 * * *$ & $-32.3 * * *$ & $-32.3 * * *$ & $-32.3 * * *$ & $-32.3 * * *$ & $-33.1 * * *$ \\
\hline & $(0.594)$ & $(0.594)$ & $(0.594)$ & $(0.593)$ & $(0.593)$ & $(0.593)$ & $(0.596)$ \\
\hline \multirow[t]{2}{*}{ Dummy12 } & $-35.2 * * *$ & $-35.2 * * *$ & $-35.2 * * *$ & $-35.3 * * *$ & $-35.4 * * *$ & $-35.4 * * *$ & $-37.3^{* * * *}$ \\
\hline & $(0.509)$ & $(0.509)$ & $(0.509)$ & $(0.509)$ & $(0.509)$ & $(0.509)$ & $(0.529)$ \\
\hline Pseudo R2 & 0.07 & 0.07 & 0.07 & 0.07 & 0.07 & 0.08 & 0.08 \\
\hline (-) Log Likelihood & 29312 & 29298 & 29298 & 29249 & 29239 & 29224 & 28852 \\
\hline Observations & 46,454 & 46,454 & 46,454 & 46,454 & 46,454 & 46,454 & 45,990 \\
\hline
\end{tabular}


We re-estimate the regression by dropping years of schooling and including education level dummies in place. Marginal effects (in percentages) (see also Figure3) from these probit estimation results are reported in Table 11. We again find a positive relationship between fruit and vegetable consumption and education level. the probability of alcohol consumption increases with education level. It increases by 3.58 per cent for non-graduates, 5.95 per cent for primary school graduates 8.12 per cent for middle school graduates by 8.56 per cent for high school graduates and 8.81 per cent for the individuals with university or higher degree compared to illiterates. We can conclude that people with higher levels of education are better informed about the benefits of fruit and vegetable consumption.

Table: 11

Marginal Effects from Probit Estimation for Fruit and Vegetable Consumption with Education Levels (\%)

\begin{tabular}{|c|c|c|c|c|c|c|}
\hline Variable & (1) & (2) & (3) & (4) & (5) & (6) \\
\hline & \multicolumn{6}{|c|}{ Education } \\
\hline \multirow[t]{2}{*}{ Non-Graduate } & $4.49 * * *$ & $4.53 * * *$ & $4.27 * * *$ & $4.22 * * *$ & $4.11^{* * *}$ & $3.58 * * *$ \\
\hline & $(1.05)$ & $(1.05)$ & $(1.05)$ & $(1.05)$ & $(1.05)$ & $(1.06)$ \\
\hline \multirow[t]{2}{*}{ Primary School } & $8.07 * * *$ & $8.12 * * *$ & $7.75 * * *$ & $7.78 * * *$ & $7.73 * * *$ & $5.95 * * *$ \\
\hline & $(0.672)$ & $(0.68)$ & $(0.73)$ & $(0.74)$ & $(0.73)$ & $(0.75)$ \\
\hline \multirow[t]{2}{*}{ Middle School } & $12.1^{* * *}$ & $12.21 * * *$ & $11.06^{* * * *}$ & $10.96^{* * * *}$ & $10.97 * * *$ & $8.12 * * *$ \\
\hline & $(0.938)$ & $(0.95)$ & $(1.02)$ & $(1.02)$ & $(1.02)$ & $(1.04)$ \\
\hline \multirow[t]{2}{*}{ High School } & $13.9^{* * *}$ & $14.02 * * *$ & $12.56^{* * * *}$ & $12.35^{* * * *}$ & $12.45^{* * * *}$ & $8.56^{* * *}$ \\
\hline & $(0.816)$ & $(0.83)$ & $(0.92)$ & $(0.92)$ & $(0.92)$ & $(0.97)$ \\
\hline \multirow[t]{2}{*}{ University+ } & $16.2 * * *$ & $16.27 * * *$ & $14.58 * * *$ & $14.12 * * *$ & $14.63^{* * *}$ & $8.81 * * *$ \\
\hline & $(0.865)$ & $(0.88)$ & $(0.97)$ & $(0.98)$ & $(0.99)$ & (1.08) \\
\hline Pseudo R2 & 0.07 & 0.07 & 0.07 & 0.07 & 0.08 & 0.08 \\
\hline (-) Log-Likelihood & 29297 & 29297 & 29250 & 29239 & 29224 & 28853 \\
\hline $\mathbf{N}$ & 46454 & 46454 & 46454 & 46454 & 46454 & 45990 \\
\hline
\end{tabular}

Figure: 3

Marginal Effects (x100) on Probability of Fruit and Vegetable Consumption by Education Level

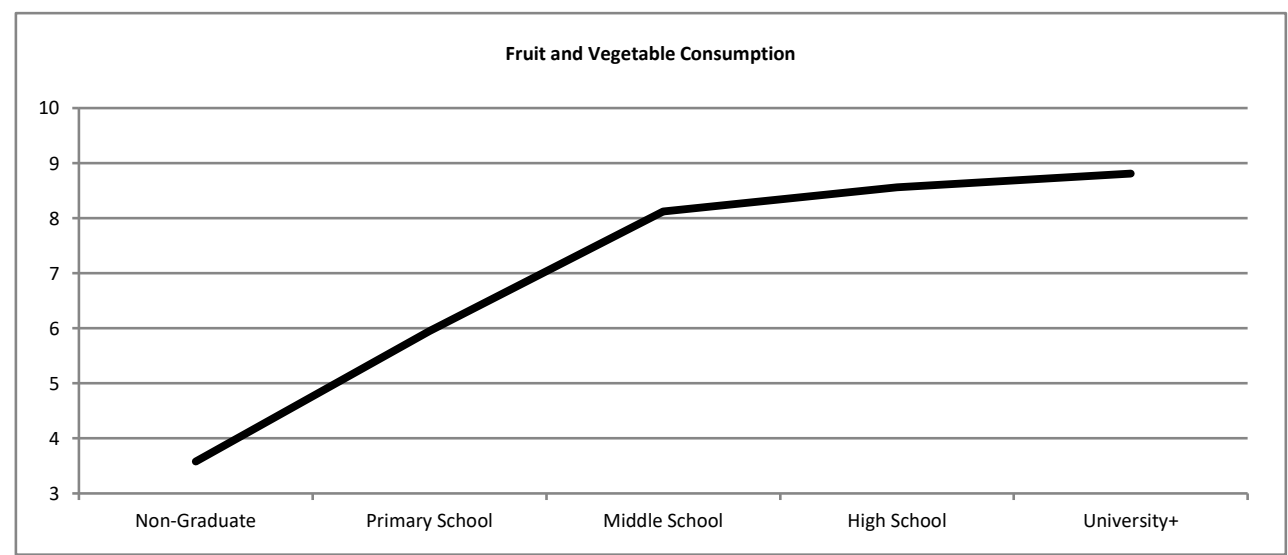

Source: THS 2008, 2010 and 2012 pooled data set.

We now consider the rest of the covariates. We observe that males are more likely to consume fruits and vegetables than females. The probability of fruit and vegetable 
consumption and age has a U-shape relationship indicating an initial decline up to age 56 and an increase afterwards. Urban residents tend to consume more fruit and vegetables than rural ones. Singles tend to consume more fruits and vegetables than the widowed/divorced while the marginal effect for the married is not significantly different from the latter group. The probability of consuming fruit and vegetables for the employed and unemployed individuals is significantly smaller than that of the inactive. Finally, as household income increases the probability of consuming fruits and vegetables also increases.

\subsection{Exercise}

Table 12 shows the marginal effects (in percentages) from probit estimation results for exercise behavior. We find that regular exercise is positively and significantly associated with education level. The probability of exercise increases by 2.65 percentage points when years of schooling increase by a year.

Table: 12

\begin{tabular}{|c|c|c|c|c|c|c|c|}
\hline VARIABLES & (1) & (2) & (3) & (4) & (5) & (6) & (7) \\
\hline Years of Schooling & $1.40^{* * * *}$ & $4.24^{* * * *}$ & $3.9 * * *$ & $2.8^{* * *}$ & $2.77^{* * * *}$ & $2.84 * * *$ & $2.81^{* * * *}$ \\
\hline Years of Schooling Square & & $\begin{array}{c}-0.19^{* * * *} \\
(0.0099)\end{array}$ & $\begin{array}{c}-0.175^{* * *} * \\
(0.01)\end{array}$ & $\begin{array}{c}-0.116 * * * \\
(0.0104)\end{array}$ & $\begin{array}{c}-0.114 * * * \\
(0.0105)\end{array}$ & $\begin{array}{c}-0.123^{* * * *} \\
(0.0105)\end{array}$ & $\begin{array}{c}-0.123^{* * * *} \\
(0.0106)\end{array}$ \\
\hline Male & & & $\begin{array}{c}4.56^{* * * *} \\
(0.454)\end{array}$ & $\begin{array}{c}5.21 * * * \\
(0.457)\end{array}$ & $\begin{array}{l}5.14 * * * \\
(0.466)\end{array}$ & $\begin{array}{l}3.17 * * * \\
(0.544)\end{array}$ & $\begin{array}{c}3.31^{* * * *} \\
(0.548)\end{array}$ \\
\hline $\operatorname{Age}\left(\times 10^{-1}\right)$ & & & & $\begin{array}{l}15.3^{* * * *} \\
(0.897)\end{array}$ & $\begin{array}{l}14.7^{* * * *} \\
(0.938)\end{array}$ & $\begin{array}{l}14.5^{* * * *} \\
(0.933)\end{array}$ & $\begin{array}{l}14.4 * * * \\
(0.943)\end{array}$ \\
\hline Age Square $\left(\mathbf{x 1 0}^{-3}\right)$ & & & & $\begin{array}{c}-17.3 * * * * \\
(0.864)\end{array}$ & $\begin{array}{c}-16.7^{* * * *} \\
(0.903)\end{array}$ & $\begin{array}{c}-16.0^{* * * *} \\
(0.903)\end{array}$ & $\begin{array}{c}-16.0^{* * *} \\
(0.91)\end{array}$ \\
\hline Urban & & & & $\begin{array}{c}-4.76^{* * * *} \\
(0.501)\end{array}$ & $\begin{array}{c}-4.74 * * * * \\
(0.502)\end{array}$ & $\begin{array}{c}-4.25 * * * \\
(0.506) \\
\end{array}$ & $\begin{array}{c}-4.22 * * * * \\
(0.522) \\
\end{array}$ \\
\hline \multicolumn{8}{|c|}{ Marital Status } \\
\hline Married & & & & & $\begin{array}{c}1.08 \\
(0.777)\end{array}$ & $\begin{array}{c}1.48^{*} \\
(0.779)\end{array}$ & $\begin{array}{c}1.24 \\
(0.785)\end{array}$ \\
\hline Single & & & & & $\begin{array}{l}-0.616 \\
(1.14) \\
\end{array}$ & $\begin{array}{l}-0.122 \\
(1.15) \\
\end{array}$ & $\begin{array}{c}-0.440 \\
(1.15) \\
\end{array}$ \\
\hline \multicolumn{8}{|c|}{ Labor Force Status } \\
\hline Employed & & & & & & $\begin{array}{l}4.36^{* * * *} \\
(0.575)\end{array}$ & $\begin{array}{l}4.33 * * * \\
(0.579)\end{array}$ \\
\hline Unemployed & & & & & & $\begin{array}{l}0.454 \\
(1.35)\end{array}$ & $\begin{array}{l}0.464 \\
(1.37)\end{array}$ \\
\hline Log Household Income & & & & & & & $(0.445)$ \\
\hline Dummy10 & $\begin{array}{c}6.19 * * * \\
(0.617)\end{array}$ & $\begin{array}{l}6.29^{* * * *} \\
(0.614)\end{array}$ & $\begin{array}{l}6.41^{* * * *} \\
(0.614)\end{array}$ & $\begin{array}{c}6.77 * * * * \\
(0.609)\end{array}$ & $\begin{array}{c}6.77 * * * * \\
(0.609)\end{array}$ & $\begin{array}{c}6.74 * * * * \\
(0.609)\end{array}$ & $\begin{array}{l}6.72^{* * * *} \\
(0.613)\end{array}$ \\
\hline Dummy12 & $\begin{array}{l}1.59 * * * * \\
(0.532)\end{array}$ & $\begin{array}{c}1.64 * * * * \\
(0.53)\end{array}$ & $\begin{array}{c}1.71 * * * * \\
(0.53)\end{array}$ & $\begin{array}{l}2.27 * * * * \\
(0.527)\end{array}$ & $\begin{array}{c}2.28 * * * * \\
(0.527)\end{array}$ & $\begin{array}{l}2.25 * * * \\
(0.527)\end{array}$ & $\begin{array}{c}2.25 * * * \\
(0.549)\end{array}$ \\
\hline $\begin{array}{l}\text { Pseudo R2 } \\
\text { (-)Log Likelihood }\end{array}$ & $\begin{array}{c}0.02 \\
29338\end{array}$ & $\begin{array}{c}0.02 \\
29161\end{array}$ & $\begin{array}{c}0.02 \\
29111\end{array}$ & $\begin{array}{c}0.03 \\
28775\end{array}$ & $\begin{array}{c}0.03 \\
28772\end{array}$ & $\begin{array}{c}0.04 \\
28742\end{array}$ & $\begin{array}{c}0.04 \\
28444\end{array}$ \\
\hline Observations & 43605 & 43605 & 43605 & 43605 & 43605 & 43605 & 43206 \\
\hline
\end{tabular}

We re-estimate the regression by dropping years of schooling and including education level dummies in place. Marginal effects (in percentages) (see also Figure 4) from these probit estimation results are reported in Table 13. We again find a positive relationship between exercise and education level. The probability of exercise increases with education level. It increases by 8.80 percentage points for non-graduates, 11.57 per cent for primary school graduates 14.94 per cent for middle school graduates by 15.10 percent for high school graduates and 15.57 percent for the individuals with university or higher degree compared 
to illiterates. Our results are consistent with previous literature findings. For instance, the studies for developed countries such as Kenkel (1991) and Lantz et al. (2001) in the USA also find a positive relationship between schooling and exercise.

Table: 13

\begin{tabular}{lllllll}
\multicolumn{6}{c}{ Marginal Effects from Probit Estimation for Exercise with Education Levels (\%) } \\
\hline Variable & $(1)$ & $(2)$ & $(3)$ & $(4)$ & $(5)$ & $(6)$ \\
\hline & & & & Education & & \\
Non-Graduate & $11.1^{* * *}$ & $10.21^{* * *}$ & $8.89^{* * *}$ & $8.78^{* * *}$ & $8.96^{* * *}$ & $8.80^{* * * *}$ \\
& $(1.04)$ & $(1.06)$ & $(1.06)$ & $(1.06)$ & $(1.06)$ & $(1.06)$ \\
Primary School & $18.5^{* * *}$ & $16.80^{* * *}$ & $11.77^{* * *}$ & $11.56^{* * *}$ & $11.64^{* * *}$ & $11.57^{* * *}$ \\
& $(0.649)$ & $(0.68)$ & $(0.73)$ & $(0.74)$ & $(0.74)$ & $(0.75)$ \\
Middle School & $22.7^{* * *}$ & $20.26^{* * *}$ & $15.29^{* * *}$ & $15.19^{* * *}$ & $15.11^{* * *}$ & $14.94^{* * *}$ \\
& $(0.922)$ & $(0.96)$ & $(1.03)$ & $(1.03)$ & $(1.03)$ & $(1.05)$ \\
High School & $22.5^{* * *}$ & $20.56^{* * *}$ & $15.59^{* * *}$ & $15.55^{* * *}$ & $15.26^{* * *}$ & $15.10^{* * *}$ \\
& $(0.795)$ & $(0.83)$ & $(0.92)$ & $(0.93)$ & $(0.93)$ & $(0.97)$ \\
University+ & $23.8^{* * *}$ & $21.49^{* * *}$ & $16.82^{* * *}$ & $16.90^{* * *}$ & $15.82^{* * *}$ & $15.57^{* * *}$ \\
& $(0.847)$ & $(0.88)$ & $(0.97)$ & $(0.98)$ & $(0.99)$ & $(1.08)$ \\
Pseudo R2 & 0.02 & 0.02 & 0.04 & 0.04 & 0.04 & 0.04 \\
$(-)$ Log-Likelihood & 29140 & 27076 & 26773 & 26767 & 26741 & 26476 \\
\hline $\mathbf{N}$ & 43605 & 43605 & 43605 & 43605 & 43605 & 43206 \\
\hline
\end{tabular}

Figure: 4

Marginal Effects (x100) on Probability of Exercise by Education Level

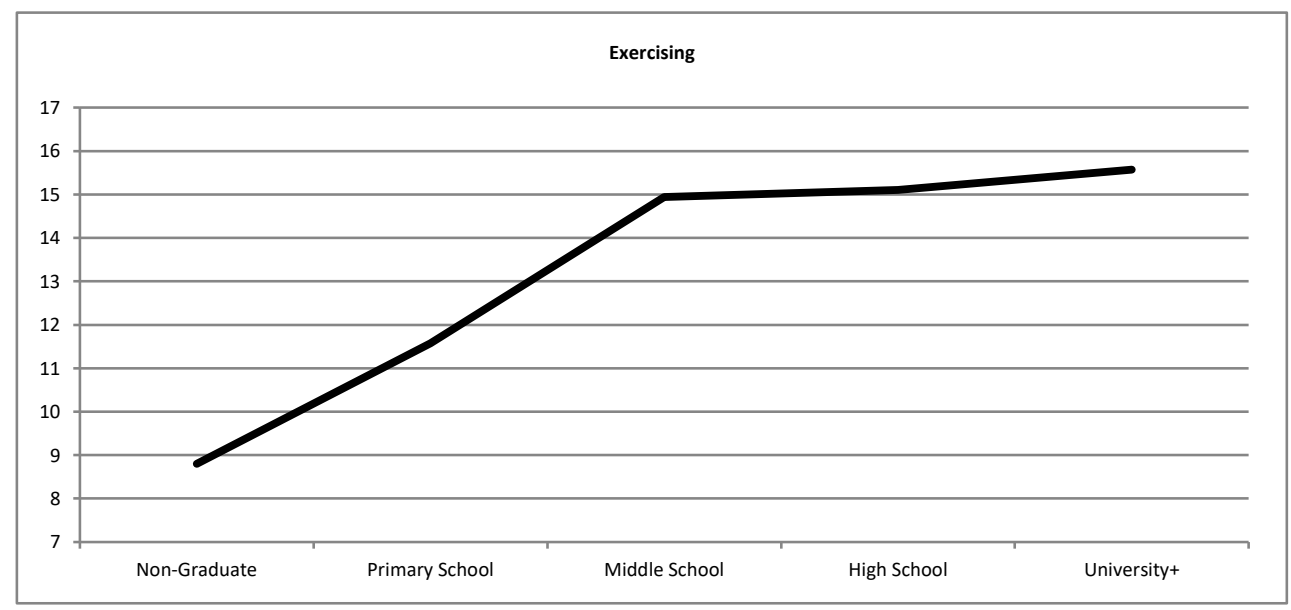

Source: THS 2008, 2010 and 2012 pooled data set.

We now consider the rest of the covariates. Males tend to exercise than the females. The probability of exercise and age has a concave relationship: Individuals are more likely to exercise as they get older, but roughly at age 46, probability of exercise starts to decrease. Rural residents tend to exercise more than the urban ones. The probability of exercise is significantly higher for the married people than for the widowed/divorced, whereas exercise behavior of single individuals do not significantly differ from that of widowed/divorced. Employed individuals tend to exercise significantly more than inactive while the exercise behavior of the unemployed is not significantly different from that of the inactive. The probability of exercise increases by 4.11 percentage points if the individual is employed. 
These results are consistent with our expectations, since employed people are physically more active than the unemployed or the inactive. Finally, our results suggest that household income does not significantly affect the exercise behavior of the individual.

\subsection{Obesity}

Table 14 presents the probit estimation results where the dependent variable shows whether the individual is obese. We find that an increase in years of schooling results with less probability of being obese. This result is similar to the results of the previous literature such as Kemptner et al. (2011), Brunello et al. (2016), Webbink et al (2010), Cutler and Llearas-Muney (2010) and Lantz et al. (2001). We find that one-year increase in years of schooling leads to 0.4 per cent decrease in individual's probability of being obese when we control all socioeconomic and demographic factors.

Table: 14

Probit Estimation for Obesity with Years of Schooling

\begin{tabular}{|c|c|c|c|c|c|c|c|}
\hline VARIABLES & (1) & $(2)$ & (3) & (4) & (5) & (6) & (7) \\
\hline \multirow[t]{2}{*}{ Years of Schooling } & $-1.34 * * *$ & $-1.28 * * *$ & $-0.814 * * *$ & $-0.306^{*}$ & $-0.342^{* * *}$ & $-0.385^{* *}$ & $-0.462 * * *$ \\
\hline & $(0.0469)$ & $(0.154)$ & $(0.156)$ & $(0.165)$ & $(0.165)$ & $(0.166)$ & $(0.168)$ \\
\hline \multirow[t]{2}{*}{ Years of Schooling Square } & & -0.00407 & $-0.0233 * *$ & $-0.0312 * * *$ & $-0.0264 * * *$ & $-0.0222 * *$ & $-0.0233 * *$ \\
\hline & & $(0.00975)$ & $(0.00986)$ & $(0.01)$ & $(0.01)$ & $(0.0101)$ & $(0.0102)$ \\
\hline \multirow[t]{2}{*}{ Male } & & & $-6.46^{* * *}$ & $-7.66^{* * *} *$ & $-7.51 * * *$ & $-6.12 * * *$ & $-5.99 * * *$ \\
\hline & & & $(0.406)$ & $(0.406)$ & $(0.414)$ & $(0.484)$ & $(0.49)$ \\
\hline \multirow[t]{2}{*}{$\operatorname{Age}\left(\mathbf{x 1 0}^{-1}\right)$} & & & & $31.0 * * *$ & $29.6 * * *$ & $29.5 * * *$ & 29.1 **** \\
\hline & & & & $(0.937)$ & $(0.962)$ & $(0.967)$ & $(0.974)$ \\
\hline \multirow[t]{2}{*}{$\operatorname{Age} \operatorname{Square}\left(\mathbf{x 1 0}^{-3}\right)$} & & & & $-26.9 * * *$ & $-25.8 * * *$ & $-26.2 * * *$ & $-25.7 * * *$ \\
\hline & & & & $(0.919)$ & $(0.943)$ & $(0.954)$ & $(0.96)$ \\
\hline \multirow[t]{2}{*}{ Urban } & & & & $2.53 * * *$ & $2.47 * * *$ & $2.27 * * *$ & $1.87 * * *$ \\
\hline & & & & $(0.468)$ & $(0.469)$ & $(0.473)$ & $(0.488)$ \\
\hline \multicolumn{8}{|c|}{ Marital Status } \\
\hline Married & & & & & $\begin{array}{c}-0.622 \\
(0.694)\end{array}$ & $\begin{array}{c}-1.08 \\
(0.698)\end{array}$ & $\begin{array}{l}-1.28 * \\
(0.705)\end{array}$ \\
\hline \multirow[t]{2}{*}{ Single } & & & & & $\begin{array}{c}-7.57 * * * \\
(1.17)\end{array}$ & $\begin{array}{c}-7.33 * * * \\
(1.17)\end{array}$ & $\begin{array}{c}-7.51 * * * \\
(1.18)\end{array}$ \\
\hline & \multicolumn{7}{|c|}{ Labor Force Status } \\
\hline Employed & & & & & & $\begin{array}{c}-2.19 * * * \\
(0.514)\end{array}$ & $\begin{array}{c}-2.26^{* * * *} \\
(0.518)\end{array}$ \\
\hline Unemployed & & & & & & $\begin{array}{c}-9.72 * * * \\
(1.49)\end{array}$ & $\begin{array}{c}-8.96^{* * *} \\
(1.51)\end{array}$ \\
\hline Log Household Income & & & & & & & $\begin{array}{l}1.58 * * * * \\
(0.409)\end{array}$ \\
\hline Dummy10 & $\begin{array}{c}3.06 * * * \\
(0.578)\end{array}$ & $\begin{array}{l}3.07 * * * \\
(0.578)\end{array}$ & $\begin{array}{c}2.87 * * * \\
(0.576)\end{array}$ & $\begin{array}{c}2.18 * * * \\
(0.566)\end{array}$ & $\begin{array}{c}2.18 * * * \\
(0.566)\end{array}$ & $\begin{array}{c}2.20 * * * \\
(0.566)\end{array}$ & $\begin{array}{l}2.02 * * * \\
(0.571)\end{array}$ \\
\hline Dummy12 & $\begin{array}{l}3.21 * * * \\
(0.504)\end{array}$ & $\begin{array}{l}3.21 * * * \\
(0.504)\end{array}$ & $\begin{array}{c}3.03 * * * \\
(0.503)\end{array}$ & $\begin{array}{l}2.15 * * * \\
(0.495)\end{array}$ & $\begin{array}{l}2.17 * * * \\
(0.495)\end{array}$ & $\begin{array}{l}2.15 * * * \\
(0.495)\end{array}$ & $\begin{array}{l}1.64 * * * \\
(0.515)\end{array}$ \\
\hline Pseudo R2 & 0.02 & 0.02 & 0.03 & 0.06 & 0.06 & 0.06 & 0.06 \\
\hline (-)Log Likelihood & 21051 & 21051 & 20930 & 20146 & 20118 & 20091 & 19915 \\
\hline Observations & 41,074 & 41,074 & 41,074 & 41,074 & 41,074 & 41,074 & 40,699 \\
\hline
\end{tabular}

Table 15 reports probit estimation results where we drop years of schooling and add dummy variables for education levels instead (see also Figure 5). Our results suggest that the likelihood of being obese for non-graduate people is significantly higher compared to illiterate individuals. For other education groups, we observe that as education level increases, the individual's probability of being obese rises. The negative marginal effect is of education on individual's probability of being obese is highest for the individuals with university or higher degree. This result suggests that more educated people are better informed about the risks of overweight or obesity. 
Table: 15

Probit Estimation for Obesity with Education Levels

\begin{tabular}{lcccccc}
\hline VARIABLES & $(1)$ & $(2)$ & $(3)$ & $(4)$ & \multicolumn{1}{c}{$(5)$} & $(6)$ \\
\hline Non-Graduate & 0.488 & $1.75^{*}$ & $2.16^{* *}$ & $2.17^{* *}$ & $2.09^{* *}$ & $2.01^{* *}$ \\
& $(0.995)$ & $(0.989)$ & $(0.966)$ & $(0.965)$ & $(0.964)$ & $(0.968)$ \\
Primary School & $-4.30^{* * *}$ & $-2.27^{* * *}$ & -1.00 & -1.07 & $-1.16^{*}$ & $-1.62^{* *}$ \\
& $(0.661)$ & $(0.667)$ & $(0.699)$ & $(0.699)$ & $(0.698)$ & $(0.710)$ \\
Middle School & $-11.0^{* * *}$ & $-8.11^{* * *}$ & $-3.95^{* * *}$ & $-3.9^{* * *}$ & $-3.96^{* * *}$ & $-4.59^{* * *}$ \\
& $(0.89)$ & $(0.9)$ & $(0.941)$ & $(0.941)$ & $(0.94)$ & $(0.962)$ \\
High School & $-14.6^{* * *}$ & $-11.9^{* * *}$ & $-7.10^{* * *}$ & $-6.88^{* * *}$ & $-6.88^{* * *}$ & $-7.81^{* * *}$ \\
& $(0.794)$ & $(0.8)$ & $(0.861)$ & $(0.862)$ & $(0.861)$ & $(0.904)$ \\
University+ & $-17.4^{* * *}$ & $-14.4^{* * *}$ & $-9.85^{* * *}$ & $-9.31^{* * *}$ & $-8.97^{* * *}$ & $-10.4^{* * *}$ \\
& $(0.85)$ & $(0.855)$ & $(0.915)$ & $(0.92)$ & $(0.929)$ & $(1.01)$ \\
Pseudo R2 & 0.02 & 0.03 & 0.06 & 0.06 & 0.06 & 0.06 \\
(-) Log-Likelihood & 21032 & 20909 & 20139 & 20111 & 20084 & 19908 \\
Observations & 41,074 & 41,074 & 41,074 & 41,074 & 41,074 & 40,699 \\
\hline
\end{tabular}

Figure: 5

Marginal Effects (x100) on Probability of Being Obese by Education Level

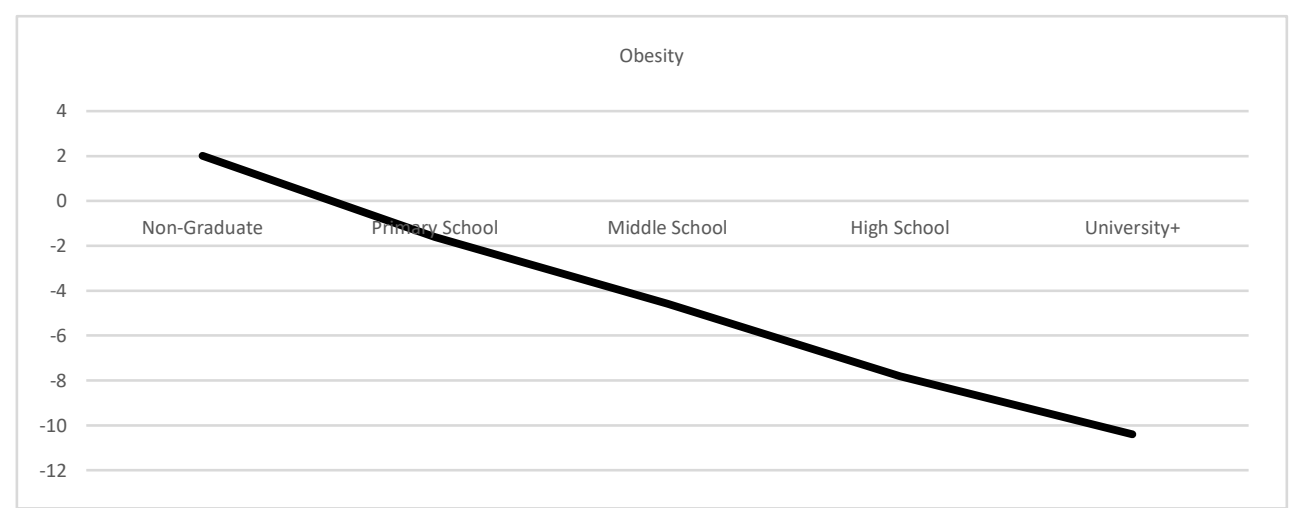

Source: THS 2008, 2010 and 2012 pooled data set.

We now consider the rest of the covariates. Females are significantly more likely to be obese than males. Probability of being obese increases with age at a decreasing rate. Urban residents are more likely to be obese than rural ones. Our results indicate that single individuals are significantly less likely to be obese, whereas the probability of being obese does not significantly vary between married and widowed/divorced individuals. Next, we find that both employed and unemployed individuals have less tendency to be obese than the inactive. This may be due to the more sedentary life-styles of inactive people. Finally, we find that increase in household income causes a rise in the probability of being obese.

\section{Conclusion}

This article investigates the determinants of health behaviors in Turkey with a focus on education. The correlation between education and health behaviors is widely investigated and well established. In this study, we do not attempt to estimate the causal relationships but only establish the correlations between health behaviors and their determining factors. The health behaviors considered are smoking, alcohol consumption, fruit and vegetable 
consumption, exercise and the health outcome is obesity. We consider both the years of schooling and the different levels of education in order to better understand the relationship between education and health. Other factors considered include demographic factors, such as gender, age and the marital status as well as urban/rural location, employment status, and the household income. In conclusion, we find that health behaviors, as well as obesity, and education are strongly related to each other in Turkey. Unlike in the developed countries, the probability of smoking increases with education. However, the association of university or higher education is smaller than the effects of lower levels of schooling. In other words, although the probability of smoking is positively associated with education at all levels this effect decreases with the levels of education. We can conclude that smoking is a serious public health problem in Turkey at all levels of education. The probability of eating fruits and vegetables is higher among the better educated compared to the less educated and illiterate. We also find that higher educated individuals exercise more. Next, we observe that higher educated individuals clearly have less tendency to be obese. The only exception is the alcohol consumption where higher educated individuals tend to consume more alcohol in Turkey than the less educated.

Further, it is worthy to note that higher levels of income are associated with higher alcohol consumption, fruit and vegetable consumption and probability of being obese. The association of income with the probabilities of smoking and exercise are not significant. Males tend to consume more tobacco and alcohol than females. They are also more likely to consume fruits and vegetables and exercise more than females. Finally, females are more likely to be obese than males.

Therefore, one can conclude that public health policies (for instance, campaigns against obesity or promoting healthy nutrition) will be more effective if an individual's education level increases. (Karaoğlan \& Tansel (2018)). Campaigns against obesity and for exercising more often should be directed towards women since they are more likely to be obese than men and exercise less than men. Education cannot be a relevant policy tool to deter smoking in Turkey since smoking is prevalent at all education levels. However, information campaigns for the harmful effects of smoking could be directed to all education levels. Increasing education levels of the population will increase the probability of fruit and vegetable consumption and also exercising. This will lead to healthier individuals. The findings in this paper will be useful to both policy makers and researchers and hopefully stimulate future research in the area of determining factors and health behaviors nexus. Investigating the causal links is the challenge in the future studies.

\section{References}

Bolin, K. (2011), "Health Production", in: S. Glied \& P.C. Smith (eds.), Oxford Handbook of Health Economics, New York: Oxford University Press, 95-123.

Brunello, G. \& D. Fabbri \& M. Fort (2013), "The Causal Effect of Education on Body Mass:

Evidence from Europe", Journal of Labor Economics, 31(1), 195-223.

Brunello, G., et al. (2016), "The Causal Effect of Education on Health: What is the Role of Health Behaviors?", Health Economics, 25(3), 314-336. 
Carbone, J.C. \& S. Kverndokk \& O.J. Røgeberg (2005), "Smoking, Health, Risk, and Perception”, Journal of Health Economics, 24(4), 631-653.

Case, A. \& C. Paxson (2005), "Sex Differences in Morbidity and Mortality", Demography, 42(2), 189-214.

Cesur, R. \& B. Dursun \& N. Mocan (2014), "The Impact of Education on Health and Health Behavior in a Middle-Income, Low-Education Country", Cambridge, MA: National Bureau of Economic Research (NBER) Working Paper No. 20764.

Chaloupka, F.J. \& K.E. Warner (2000), “The Economics of Smoking”, in: A.J. Culyer \& J.P. Newhouse (eds.), Handbook of Health Economics, Vol. 1, Amsterdam: Elsevier, 15391627.

Cutler, D.M. \& E.L. Glaeser \& J.M. Shapiro (2003), "Why Have Americans Become More Obese?”, The Journal of Economic Perspectives, 17(3), 93-118.

Cutler, D.M. \& E.L. Glaeser (2005), "What Explains Differences in Smoking, Drinking, and Other Health-Related Behaviors?", The American Economic Review, 95(2), 238-242.

Cutler, D.M. \& A. Lleras-Muney (2008), "Education and Health: Evaluating Theories and Evidence", in: S.H. James \& R.F. Schoeni \& G.A. Kaplan \& H. Pollack (eds.), Making Americans Healthier: Social and Economic Policy as Health Policy, New York: Russel Sage Foundation.

Cutler, D.M. \& A. Lleras-Muney (2010), "Understanding Differences in Health Behaviors by Education", Journal of Health Economics, 29(1), 1-28.

Cutler, D.M. \& A. Lleras-Muney \& T. Vogl (2011), "Socioeconomic Status and Health: Dimensions and Mechanisms", in: S. Glied \& P.C. Smith (eds.), Oxford Handbook of Health Economics, New York: Oxford University Press, 124-163.

De Walque, D. (2007), "Does Education Affect Smoking Behaviors?: Evidence Using the Vietnam Draft as an Instrument for College Education", Journal of Health Economics, 26(5), 877895.

Erem, C., et al. (2004), "Prevalence of Obesity and Associated Risk Factors in a Turkish Population (Trabzon City, Turkey)", Obesity Research, 12(7), 1117-1127.

Erbaydar, T., et al. (2005), "Influence of Social Environment in Smoking among Adolescents in Turkey", The European Journal of Public Health, 15(4), 404-410.

Ettner, S.L. (1996), "New Evidence on the Relationship between Income and Health", Journal of Health Economics, 15(1), 67-85.

Fletcher, G.F., et al. (1996), "Statement on Exercise: Benefits and Recommendations for Physical Activity Programs for All Americans A Statement for Health Professionals by the Committee on Exercise and Cardiac Rehabilitation of the Council on Clinical Cardiology, American Heart Association”, Circulation, 94(4), 857-862.

Fuchs, V.R. (2004), "Reflections on the Socio-Economic Correlates of Health", Journal of Health Economics, 23(4), 653-661.

García, V.J. \& C. Quintana-Domeque (2009), "Income and Body Mass Index in Europe”, Economics \& Human Biology, 7(1), 73-83.

Grossman, M. (1972), “On the Concept of Health Capital and the Demand for Health”, Journal of Political Economy, 80(2), 223-255.

Grossman, M. (2000), “The Human Capital Model”, in: A.J. Culyer \& J.P. Newhouse (eds.), Handbook of Health Economics, Vol.1. Amsterdam: Elsevier, 348-408. 
Grossman, M. (2004), “The Demand for Health, 30 Years Later: A Very Personal Retrospective and Prospective Reflection”, Journal of Health Economics, 23(4), 629-636.

Gruber, J. \& M. Frakes (2006), “Does Falling Smoking Lead to Rising Obesity?”, Journal of Health Economics, 25(2), 183-197.

Hatemi, H., et al. (2003), "Prevalence of Overweight and Obesity in Turkey", Metabolic Syndrome and Related Disorders, 1(4), 285-290.

Hung, H-C., et al. (2004), "Fruit and Vegetable Intake and Risk of Major Chronic Disease", Journal of the National Cancer Institute, 96(21), 1577-1584.

Karaoğlan, D. (2015), "Essays on Education Gradient of Health in Turkey”, Unpublished Disserrtation, Ankara, Turkey: Department of Economics, Middle East Technical University.

Karaoğlan, D. \& A. Tansel (2018), "Determinants of Body Mass Index in Turkey: A Quantile Regression Analysis from a Developing Country", Boğaziçi Journal Review of Social, Economic and Administrative Studies, 32(2), 1-17, doi no:10.21773/boun.32.2.1.

Kemptner, D. \& H. Jürges \& S. Reinhold (2011), "Changes in Compulsory Schooling and the Causal Effect of Education on Health: Evidence from Germany", Journal of Health Economics, 30(2), 340-354.

Kenkel, D.S. (1991), "Health Behavior, Health Knowledge, and Schooling”, Journal of Political Economy, 99(2), 287-305.

Kocabas, A., et al. (1994), "Smoking Patterns at Different Medical Schools in Turkey", Tobacco Control, 3(3), 228-235.

Lantz, P.M., et al. (1998), "Socioeconomic Factors, Health Behaviors, and Mortality", JAMA: The Journal of the American Medical Association, 279(21), 1703-1708.

Lantz, P.M., et al. (2001), "Socioeconomic Disparities in Health Change in a Longitudinal Study of US Adults: The Role of Health-Risk Behaviors", Social Science \& Medicine, 53(1), 2940.

Lleras-Muney, A. (2005), "The Relationship between Education and Adult Mortality in the U.S.”, Review of Economic Studies, 72(1), 189-221.

Metintaş, S., et al. (1998), "Smoking Patterns of University Students in Eskişehir, Turkey", Public Health, 112(4), 261-264.

Mullahy, J. (1997), "Instrumental-Variable Estimation of Count Data Models: Applications to Models of Tobacco Smoking Behavior", Review of Economics and Statistics, 79(4), 586593.

OECD (2016), Health Data Set, <http://stats.oecd.org>, 28 July 2016.

Reijneveld, S.A. (2002), "Neighbourhood Socioeconomic Context and Self Reported Health and Smoking: A Secondary Analysis of Data on Seven Cities", Journal of Epidemiol Community Health, 56, 935-942.

Stewart, S.T. \& D.M. Cutler \& A.B. Rosen (2009), "Forecasting the Effects of Obesity and Smoking on US Life Expectancy", New England Journal of Medicine, 361(23), 2252-2260.

Tansel, A. (1993), "Cigarette Demand, Health Scares and Education in Turkey", Applied Economics, 25(4), 521-529.

Tansel, A. \& D. Karaoğlan (2014), "Health Behaviors and Education in Turkey", Bonn, Germany: Institute for the Study of Labor (IZA) Discussion Paper No. 8262. 
Webbink, D. \& N.G. Martin \& P.M. Visscher (2010), "Does Education Reduce the Probability of Being Overweight?", Journal of Health Economics, 29(1), 29-38.

Worldbank (2008), World Bank Report, $<$ http://siteresources.worldbank.org/NUTRITION/Resources/2818461271963823772/Turkey.pdf>, 28 July 2016.

Yumuk, V.D. (2005), "Prevalence of Obesity in Turkey", Obesity Reviews, 6(1), 9-10.

\begin{tabular}{|c|c|c|c|c|}
\hline & Defi & $\begin{array}{c}\text { Appendix } \\
\text { Table: A1 } \\
\text { nitions of Dependent Variables }\end{array}$ & & \\
\hline $\begin{array}{l}\text { Dependent } \\
\text { Variable }\end{array}$ & Related Question & Answer & Individual is refered as: & $\begin{array}{l}\text { Value of the } \\
\text { dependent } \\
\text { Variable }\end{array}$ \\
\hline Smoking & $\begin{array}{l}\text { "Were you a regular tobacco } \\
\text { consumer and do you still } \\
\text { consume tobacco?" }\end{array}$ & $\begin{array}{l}\text { Yes, everyday/Yes, sometimes } \\
\text { No }\end{array}$ & $\begin{array}{l}\text { Smoker } \\
\text { Non-Smoker }\end{array}$ & $\begin{array}{l}1 \\
0\end{array}$ \\
\hline $\begin{array}{l}\text { Alcohol } \\
\text { Consumption }\end{array}$ & $\begin{array}{l}\text { "Did you consume alcohol } \\
\text { regularly or occasionally and } \\
\text { do you still consume alcohol?" }\end{array}$ & $\begin{array}{l}\text { Yes, everyday/Yes, sometimes } \\
\text { No }\end{array}$ & $\begin{array}{l}\text { Alcohol Consumer } \\
\text { Non-Alcohol Consumer }\end{array}$ & $\begin{array}{l}1 \\
0\end{array}$ \\
\hline \begin{tabular}{l|} 
Fruit and \\
Vegetable \\
Consumption
\end{tabular} & $\begin{array}{l}\text { "How often do you consume fruits, } \\
\text { vegetables and/or their juice?" }\end{array}$ & $\begin{array}{l}\text { At least once a week. } \\
\text { Never/less than once a week }\end{array}$ & $\begin{array}{l}\text { Fruit and Vegetable } \\
\text { Consumer } \\
\text { Non Fruit and } \\
\text { Vegetable Consumer }\end{array}$ & 1 \\
\hline Exercise & $\begin{array}{l}\text { "How often do you make high } \\
\text { level/medium level/low level } \\
\text { exercise" }\end{array}$ & $\begin{array}{l}\text { The individual reports that he/she makes any type of } \\
\text { the exercise at least } 10 \text { minutes in the reference week } \\
\text { The individual reports that he/she never makes any type } \\
\text { of the exercise }\end{array}$ & $\begin{array}{l}\text { The individual exercises } \\
\text { regularly } \\
\text { The individual does not } \\
\text { exercise regularly }\end{array}$ & 0 \\
\hline Obesity & $\begin{array}{l}\text { Individual weight and height are } \\
\text { asked and his/her BMI is calculated: } \\
\qquad B M I=\frac{\text { Weight }}{\text { Height }^{2}}\end{array}$ & $\begin{array}{l}\text { BMI }>=30 \\
\text { BMI }<30\end{array}$ & $\begin{array}{l}\text { Obese } \\
\text { Not Obese }\end{array}$ & 1 \\
\hline
\end{tabular}

Table: A2

Definitions of Independent Variables

\begin{tabular}{|c|c|}
\hline Independent Variable & Value \\
\hline Years of Schooling & $\begin{array}{l}0 \text { for illiterates } \\
2 \text { for non-graduates } \\
5 \text { for primary school graduates } \\
8 \text { for middle school graduates } \\
11 \text { for high school graduates } \\
15 \text { for university or higher degree }\end{array}$ \\
\hline \multicolumn{2}{|l|}{ Education Dummies } \\
\hline Illiterate & 1 for illiterates, 0 otherwise \\
\hline Non-graduated & 1 for non-graduates, 0 otherwise \\
\hline Primary School & 1 for Primary Schhol Graduates, 0 otherwise \\
\hline Middle School & 1 for Middle School Graduates, 0 otherwise \\
\hline High School & 1 for High School Graduates, 0 otherwise \\
\hline University+ & 1 for individuals with university or higher degree, 0 otherwise \\
\hline Gender & 1 for males, 0 for females \\
\hline Age & Reported age by the respondent (continous variable) \\
\hline Place of residence & 1 for urban, 0 for rural \\
\hline \multicolumn{2}{|l|}{ Marital Status Dummies } \\
\hline Married & 1 for married, 0 otherwise \\
\hline Single & 1 for single, 0 otherwise \\
\hline Widowed/divorced & 1 for widowed/divorced, 0 otherwise \\
\hline \multicolumn{2}{|c|}{ Labor Force Status Dummies } \\
\hline Employed & 1 for employed, 0 otherwise \\
\hline Unemployed & 1 for unemployed, 0 otherwise \\
\hline Inactive & 1 for inactive, 0 otherwise \\
\hline $\begin{array}{l}\text { Household income (in } \\
\text { logarithms) }\end{array}$ & $\begin{array}{l}\text { net monthly income is given in brackets (less than } 350,351-500,501-620,621-750,751-900,910-1100,1101-1300 \text {, } \\
1301-1700,1701-2300 \text {, more than } 2301 \text {, all in TL). We take the logarithms of the midpoints }\end{array}$ \\
\hline
\end{tabular}

